\title{
Principles guiding practice: A case study analysis of the principles of sustainable agriculture for diverse farms
}

\author{
Kelly N. Moore ${ }^{a} *$ and Marilyn E. Swisher ${ }^{b}$ \\ University of Florida \\ Juan Carlos Rodriguez ${ }^{\mathrm{c}}$ \\ Roca Consulting Group, LLC \\ Mark Blevins ${ }^{\mathrm{d}}$ \\ Brunswick County Extension Services, \\ North Carolina State University \\ Michael Hogan ${ }^{\mathrm{e}}$ \\ The Ohio State University \\ Lauren Hunter ${ }^{\mathrm{f}}$ \\ Blain County Extension Services, University \\ of Idaho
}

\author{
Christine Kelly-Begazo ${ }^{g}$ \\ Indian River County Extension Services, \\ University of Florida \\ Stephen Komar ${ }^{\mathrm{h}}$ \\ Cooperative Extension of Sussex County, \\ Rutgers New Jersey Agricultural \\ Experiment Station \\ Suzanne Mills-Wasniak ${ }^{\mathrm{i}}$ \\ Montgomery County Extension Services, The \\ Ohio State University \\ David Redhage ${ }^{j}$ \\ Kerr Center for Sustainable Agriculture
}

Submitted August 6, 2015 / Revised November 6 and December 4, 2015, and February 3, 2016 /

Accepted February 3, 2016 / Published online June 20, 2016

Citation: Moore, K. N., Swisher, M. E., Rodriguez, J. C., Blevins, M., Hogan, M., Hunter, L., Kelly-Begazo, C., Komar, S., Mills-Wasniak, S., \& Redhage, D. (2016). Principles guiding practice: A case study analysis of the principles of sustainable agriculture for diverse farms. Journal of Agriculture, Food Systems, and Community

Development, 6(3), 61-89. http://dx.doi.org/10.5304/jafscd.2016.063.008

Copyright (C) 2016 by New Leaf Associates, Inc.

\section{Abstract \\ Early proponents of sustainable agriculture faced considerable resistance and initiated a long-lasting discussion over strategies for sustainable}

a $*$ Corresponding author: Kelly N. Moore, School of Natural Resources and Environment, University of Florida; P.O. Box 110310; Gainesville, Florida 32611-0310 USA; +1-352-2733508; kmon913@ufl.edu

b Department of Family, Youth and Community Sciences, University of Florida; mesw@ufl.edu

c Roca Consulting Group, LLC; jcrrivera@gmail.com

d Brunswick County Extension Services, North Carolina State University; mark_blevins@ncsu.edu

e College of Food, Agricultural, and Environmental Sciences, The Ohio State University; hogan.1@,osu.edu agriculture. This controversy has re-emerged recently in the discussion of agro-ecology versus sustainable intensification. Fourteen agricultural professionals participated in a guided discovery

\footnotetext{
${ }^{\mathrm{f}}$ Blain County Extension Services, University of Idaho; lhunter@uidaho.edu

g Indian River County Extension Services, University of Florida; ckellybe@,ufl.edu

h Cooperative Extension of Sussex County, Rutgers New Jersey Agricultural Experiment Station; skomar@njaes.rutgers.edu

${ }^{i}$ Montgomery County Extension Services, The Ohio State University; mills-wasniak.1@,osu.edu

j Kerr Center for Sustainable Agriculture; dredhage@kerrcenter.com
} 
learning process on six agricultural operations in Florida that are considered to be good examples of sustainability. The six operations included large and small farms, organic and conventional farms, livestock and crop enterprises, and traditional and direct sales marketing approaches. The objective of the process was to identify the principles that the operators use to guide their specific management decisions, including decisions with economic, environmental, and social consequences. Participants studied information about each operation and created a set of questions to ask the manager(s) about the underlying philosophy and principles that guide the management and then spent one to six hours at each site. The information was analyzed in small groups after each visit, and a summative analysis was completed after all site visits were completed. Although these operations are very diverse in terms of characteristics like size, enterprise mix, farm capital, technologies used, marketing strategies, and manager experience, the study showed also similarities across the farms in the principles that guide their decision-making. From these principles, nine broad principles of sustainable agriculture were identified. Most contemporary theoretical concepts about social, economic, and environmental sustainability are reflected in the operating principles of these businesses.

\section{Keywords}

sustainable agriculture, principles, case study, discovery learning, community engagement, business principles, financial risk

\section{Introduction}

Sustainable agriculture has grown from an ideal championed primarily by environmentalists like Wes Jackson (1971) to a mainstream program of the U.S. Department of Agriculture (USDA) (Kirschenmann, 2004; USDA, Sustainable Agriculture Research \& Education Program, 2012). The call for a change in agricultural practices seemed unjustified to most in the 1970s when land values, yields, and profits were sky high, but the 1980s ushered in one of the worst farm crises in U.S. history. Thousands of farms became bankrupt. In Iowa, land values fell from US $\$ 2,147$ per acre in 1981 to US\$787 in 1986 (Duffy, 2014). Midsize farms, the traditional American family farm, were particularly hard hit, as was the Midwestern rural heartland (Brasier, 2005; Murdock, Leistritz \& Hamm, 1988). The expression "sustainable agriculture" took on a new relevance for many who had paid little attention to the concept during the booming farm economy of the 1970s. By the mid1980s, leadership for an alternative to traditional agriculture emerged and the term sustainable agriculture was adopted to embody its ideals.

The term took root, but a controversy about what sustainable agriculture is or means started almost as soon as the term appeared. Jackson's call for sustainable agriculture very quickly inspired some responses, but the formative discussion developed later, in the late 1980s and 1990s. This extended interchange was largely among proponents of the concept as a whole, as is often the case when there is a paradigm shift in any field and proponents engage in intensive debate about how to define the new paradigm (Dahlberg, 1991; Fautin, 1995; Friend, 1990; Kirschenmann, 1991; Lovett, 1990; Norman, Bloomquist, Janke, Freyenberger, Jost, Schurle, \& Kok, 2000; Reganold, Papendick \& Parr, 1990). This early dialogue focused in large part on identifying and defining the key characteristics and requisites of sustainable agricultural systems. Given the origins of the concept of sustainability in the environmental movement, it is not surprising that deliberation among proponents tended to emphasize the relationships between agriculture and the environment (Altieri, 1989; Barbier, 1989; Edwards, Grove, Harwood, \& Colfer, 1993; Hoag \& Skold, 1996; Rosegrant \& Livernash, 1996; Rosset \& Altieri, 1997; Ruttan, 1996, 2000). Proponents also soon turned their attention to the importance of economic viability for sustainability (Hitzhusen, 1992; Lighthall, 1996; Lu, Watkins \& Teasdale, 1999; Lyson \& Welsh, 1993; Madden, 1987; Marra \& Kaval, 2000; Painter, 1991; Saltiel, Bauder \& Palakovich, 1994; Walsh \& Lyson, 1997).

Although discussions of what constitutes sustainable agriculture have addressed many topics over the years, a lasting difference in conceptions has to do with the degree to which individuals see conventional and sustainable agriculture as fundamentally different ways of farming. This discussion 
has emerged most recently as a debate over the merits of ecological agriculture or agroecology versus sustainable intensification of agriculture (Entz, 2015; Illge \& Schwarze, 2009; Kershen, 2013). Two critical challenges fuel this ongoing debate about the fundamental characteristics of a sustainable food and agricultural system. One is the anticipated increase in demand for food due to population growth and increased animal protein consumption, particularly in Asia (Kastner, Rivas, Koch, \& Nonhebel, 2012; Prasad, 2013; Pretty, 2009; Tilman, Balzer, Hill, \& Befort, 2011). The other is the imperative need to allow large tracts of land to remain as natural ecosystems that will help protect as much of the planet's remaining and threatened biodiversity as possible (Dobrovolski, Loyola, Guilhauman, Gouveia, \& Diniz-Filho, 2013; Kirkegaard, Conyers, Hunt, Kirkby, Watt, \& Rebetzke, 2014; Krausmann et al., 2013; Laurance, Sayer \& Cassman, 2014; Nori, Lescano, IlloldiRangel, Frutos, Cabrera, \& Leynaud, 2013).

Ecological or agro-ecology bases agricultural research and practice on the principles and theories of ecology (Bonaudo et al., 2014; Kremen, Iles \& Bacon, 2012; Kremen \& Miles, 2012). Agroecologists conceptualize agricultural systems as humandominated ecosystems that are simpler than natural ecosystems, but have similar complex systems of interactions as natural systems. Agro-ecology proposes using these feedback loops to create more self-regulating, resilient, and resource-conserving production systems (Gleissman, 2013a; Lengnick, 2015; Miller \& Menalled, 2015; Nelson \& Coe, 2014; Omer, Pascual \& Russell, 2010; Perfecto, Vandermeer \& Philpott, 2014). These ideas reflect the deep roots of agro-ecology in a naturalist vision of agriculture (Berry, 2000; Cornes, 2011; Leopold, 1949, 1966) and to some degree in transpersonal ecology (Cox, 2014; Fix, 1995). Given these roots, it is not surprising that agroecologists have emphasized reducing energy and material flows in agroecosystems (Altieri \& Rosset, 1996; Odegard \& van der Voet, 2014; Pearson, 2007). Organic agriculture, which predates the concept of sustainable agriculture, has epitomized the practice of sustainable agriculture for many agro-ecologists (Bellows, Alcaraz \& Hallman, 2010; Cairns, Johnston \& MacKendrick, 2013; Lockie, Lyons, Lawrence, \&
Mummery, 2002; Rigby \& Caceres, 2001; Seufert, Ramankutty \& Foley, 2012; Zander \& Hamm, 2010). However, organic agriculture is no longer regarded as synonymous with sustainable agriculture for many. Increased government regulation, the growing commercialization of organic products through traditional market channels, and the development of an international system of trade in organic foods leave some questioning whether organic agriculture is now distinguishable in philosophy and approach from conventional agriculture. Many criticize this "conventionalization" of organic agriculture (Darnhofer, Lindenthal, Bartel-Kratochvil, \& Zollitsch, 2010; Gleissman, 2013b; Guthman, 2004; Jaffee \& Howard, 2010; Levidow Pimbert \& Vanloqueren, 2014; Lockie \& Halpin, 2005; Oelofse et al., 2011; Pratt, 2009). Some call for a new "beyond organic" approach that uses organic farming techniques and also builds local food systems and independent distribution networks of collaborating farmers and consumers (Cross, Edwards, Opondo, Nyeko, \& Edwards-Jones, 2009; Mundler \& Rumpus, 2012; Sonnino, 2013; Woods, Valandia, Holcomb, Dunning, \& Benefeldt, 2013). Despite the differences among those whose vision of sustainable agriculture grows out of ecology, this approach remains one of the key approaches to sustainable agriculture among researchers and farmers today.

In contrast to agro-ecology, sustainable intensification focuses on increasing yields, particularly on land already converted to agriculture (Pretty \& Bharucha, 2014). The overall strategy is to meet food needs while curbing agricultural expansion into marginal lands and into the relatively few remaining large tracts of land in natural habitat (Doré, Makowski, Malézieux, Munier-Jolain, Tchamitchian, \& Tittonell, 2011; Jordan \& Davis, 2015; Sabto, 2014). Adherents argue that ecological agriculture, especially organic agriculture, inherently leads to more land in agriculture because yields are lower than yields in more intensive production systems. Sustainable intensification is therefore characterized by some as "land saving" (Balmford, Green \& Scharlemann, 2005: Ceddia, Bardsley, Gomez-y-Paloma, \& Sedlacek, 2014; Hulme et al., 2013). Like conventional agriculture, intensification relies on the application of a wide range of 
technologies to meet production needs while preserving land and other natural resources (Barnes \& Thomson, 2014; Elliott \& Firbank, 2013; Tilman et al., 2011). However, sustainable intensification differs from conventional agriculture in its greater emphasis on technologies and practices that reduce resource use, protect ecosystem functions, and build resilience against shocks like climate change (Balwinder-Singh, Humphreys, Gaydon, \& SudhirYadav, 2015; Fish, Winter \& Lobley, 2014; Lal, 2015; Rochecouste, Dargusch, Cameron, \& Smith, 2015; van Ittersum, Cassman, Grassini, Wolf, Tittonell, \& Hochman, 2013). Some of these technologies, such as biological control, protected production systems, and soilless production systems, excite little controversy as legitimate components of sustainable agriculture (Albaho, Thomas, \& Christopher, 2008; del Amor, López-Marin, \& González, 2008; Delgado \& Berry, 2008; Maurino \& Weber, 2013; Pinkington, Messelink, van Lenteren, \& Le Mottee, 2010; Pliego, Ramos, de Vicente, \& Cazorla, 2011; Rovira-Más, \& SáizRubio, 2013; Wang \& Pang, 2013; Yang et al. 2014; ). More controversial, a growing number of proponents of sustainable intensification are convinced that application of biotechnology is a necessary element in any strategy to meet world food demand (Albajes et al., 2013; Bennett, ChiHam, Barrows, Sexton, \& Zilberman, 2013; Berkhout, 2002; Flavell, 2010; Jacobsen, Sorensen, Pedersen, \& Weiner, 2013; Mackey \& Montgomery, 2004; McGloughlin 2010; Teixeira, Proença, Crespo, Valada, \& Domingos, 2015; Wield, Chataway \& Bolo, 2010).

Embedded within the broader, underlying discussion of "ecology versus intensification" are differences in the perceived importance of various farm characteristics or production practices. Much of the discussion of what constitutes sustainable agriculture has revolved around the role of these specific practices in the achievement of sustainability. For example, for some, especially those who argue for an agroecological approach to sustainability, farm size (Gaurav \& Mishra, 2015; Kull, Carrière, Moreau, Ramiarantsoa, Blanc-Pamard, \& Tassin, 2013; Woodhouse, 2010) and the structure of farm ownership (Dogliotti et al., 2014; Fernandes \& Woodhouse, 2008; Hamilton, 2014;
Woods, 2014) are central to sustainable agriculture. Some argue that sustainable agriculture can only be achieved on small or family farms. For others, specific techniques define sustainable agriculture (Wezel, Casagrande, Celette, Vian, Ferrer, \& Peigné, 2014). Examples are integrated systems (Khan, 2011; Klinger \& Naylor, 2012; Ogello, Mlingi, Nyonje, Charo-Karis, \& Munguti, 2013), biodynamic farming (Ingram, 2007; Pechrová, 2014), and permaculture (Ferguson \& Lovell, 2014). Some practices, like the use of cover crops and crop rotation, are mandated in the U.S. National Organic Standards, while others, like the application of composted bio-solids from municipal waste processing, are specifically prohibited.

The research reported here examined the broad, underlying principles that farmers and other actors in the agri-food system use in the practice of sustainable agriculture. We explored these issues as part of a field experience supported by USDA's Sustainable Agriculture Research \& Education (SARE) Fellows Program. Each year a small cohort of members of the National Association of County Agricultural Agents (NACAA) is chosen to participate in a two-year training program, which includes field experiences in each of USDA's four regions (South, West North Central, and Northeast). Fourteen agricultural professionals participated in the 2011 field experience hosted by the University of Florida. Participants included 10 county agricultural extension agents from around the country and four regional and national SARE program representatives. They had an average of over 20 years of experience in agriculture. The group spent three days examining six agricultural operations located in the central and southeastern regions of Florida, all of which had been identified by farmers and other agricultural professionals in Florida as models of the practice of sustainable agriculture. Our overall goal was to examine whether there are generalizable principles that inform how farmers practice sustainable agriculture and that provide the platform for both daily decision-making and longterm planning.

\section{Methodology}

We used a comparative case study design for the study. Comparative case studies are explanatory in 
nature and differ from purely descriptive case study designs in important ways (Crowe, Cresswell, Robertson, Huby, Avery, \& Sheikh, 2011; Jones \& Lyons, 2004; Radley \& Chamberlain, 2012; Rubaie, 2002; Yin, 2009). Explanatory or comparative casestudy designs usually have objectives associated with reaching conclusions that are universal, at least to all of the cases examined and often that are more generally applicable to a population of cases that are similar to the cases studied in terms of their key attributes (Lloyd-Jones, 2003). Although comparative case studies are used in many sciences (Smerdon, Cook, Cook, \& Seager, 2015; Zimmermann, Aurich, Graziano, \& Fuertes, 2014), there is not a large body of literature about sustainable agriculture that uses the case study design. However, there are some studies that extend beyond description to comparison and explanation, which was our objective (Bisht et al., 2014; Boogaard, Oosting \& Bock, 2008; Cerutti, Beccaro, Bagliani, Donno, \& Bounous, 2013; Crivits \& Paredis, 2013; Davies-Jones, 2011; Girard, Magda, Nosedaz \& Sarandon, 2015).

A case-study design uses replication logic rather than statistical logic to sample and often consists of relatively few cases due to feasibility issues of larger samples (Yin, 2009). Descriptive case studies sometimes rely on a single case, but this is not a strong design; explanatory case-study designs require multiple cases. We used a nonprobability, purposive sample, an appropriate choice when the researcher needs to identify rare, hard-to-find, or hard-to-reach populations (Abrams, 2010; Auerswald, Greene, Minnis, Doherty, Ellen, \& Padian, 2004; Curtis, Gesler, Smith, \& Washburn, 2000), as was our intention here in identifying farms revered as models of sustainability.

It was imperative that we identified farms perceived by their colleagues as models of sustainability. The goal of this research was not to define what constitutes sustainable agricultural practices; there is considerable discussion around this topic already (see above discussion). Rather, it was important that these farmers were perceived to be elite models of the practice of sustainable agriculture, as our objective was to determine a common set of principles that guide their decision-making. Therefore we did not choose the farms based on characteristics like size, enterprise mix, or form of ownership, but rather on their reputation as outstanding practitioners of sustainable agriculture by other farmers and agricultural professionals. The operations differ in many other ways (Table 1$)$. They range in size from one acre ( 0.40 hectare) to 300,000 acres (121,000 hectares) and vary in management structure from family-owned to corporate. They produce a variety of products, including agronomic crops, horticultural crops, and livestock. They use both conventional and emerging

Table 1. Size, Certification, Enterprise Mix, and Marketing Strategies Used for the Six Cases Analyzed in the Study

\begin{tabular}{cllll}
\hline Case & Size & $\begin{array}{l}\text { Certification } \\
\text { (Type of certification) }\end{array}$ & $\begin{array}{l}\text { Enterprise Mix } \\
\text { (Livestock, multi- or monocrop, } \\
\text { other) }\end{array}$ & $\begin{array}{l}\text { Marketing Strategy } \\
\text { (Direct or commodity market) }\end{array}$ \\
\hline $\mathbf{1}$ & Large & $\begin{array}{l}\text { 50\% organic and 50\% } \\
\text { conventional by acreage }\end{array}$ & Multicropping & Commodity market \\
\hline $\mathbf{2}$ & Small & $\begin{array}{l}\text { Organically grown but not } \\
\text { certified organic; is certified } \\
\text { biodynamic }\end{array}$ & Multicropping, agritourism & Direct market \\
\hline $\mathbf{3}$ & Large & $\begin{array}{l}\text { 50\% organic and 50\% } \\
\text { conventional by acreage }\end{array}$ & $\begin{array}{l}\text { Monocropping with rotation, } \\
\text { agritourism, packaging, pro- } \\
\text { cessing, and distribution center }\end{array}$ & Commodity market \\
\hline $\mathbf{4}$ & Small & Cage free & Livestock & Direct market \\
\hline $\mathbf{5}$ & Small & $\begin{array}{l}\text { Organically grown but not } \\
\text { certified organic }\end{array}$ & Multicropping, livestock & Direct market \\
\hline $\mathbf{6}$ & Large & None & $\begin{array}{l}\text { Livestock, monocropping, } \\
\text { agritourism }\end{array}$ & Commodity market \\
\hline
\end{tabular}


marketing strategies, and some are managed conventionally while others are certified organic operations. This diversity permitted us to examine the degree to which differences in traits like size, ownership structure, and production system are important for sustainability. More important to us, we wanted to determine whether the operators of these farms do (or do not) share common principles that inform their practice of sustainable agriculture, regardless of differences in traits like farm size.

Our intent was to combine the SARE Fellows program learning experience with a structured or guided process of reflection and analysis drawing on grounded theory and discovery learning to identify broad principles of sustainable agriculture. Both discovery learning and grounded theory eschew a priori hypotheses and models, relying instead on the emergence of new knowledge through active experimentation. We use grounded theory as a way for researchers to approach the research process as a discovery of theory, rather than a test of theory, based on the idea that complex conceptual frameworks can emerge from the research process itself (Amsteus, 2014; Conlon, Carney, Timonen, \& Scharf, 2015; Engward, 2013; Glaser \& Strauss, 1967). However, we do not make the claim that it is a methodology that eliminates or is based on an absence of prior knowledge or ideas on the part of the researcher about the phenomenon under study (Urquhart \& Fernández, 2013). Rather, we use the approach to build existing ideas and knowledge into broader generalizations based on a reflexive research process. We used discovery learning to inform the research process because this approach to learning shares fundamental features with grounded theory and provides guidance in using interaction, direct experience, communication and deliberation with others, and prior experience to identify key concepts, analyze the relationships between them, and ultimately create generalizations based on this analysis. Grounded theory and discovery learning can foster misconceptions if implemented with learners with little experience or knowledge relevant to the task (Marzano, 2011). We did not face this risk as the professionals in the SARE Fellows program have considerable experience with sustainable agriculture and were provided relevant information prior to starting the exploration of each of the six cases.

Prior to arriving at each operation, participants received background information about each farm. This information came directly from materials provided by the operation's management or its website. Specific study objectives for each site developed by the study coordinators were provided to participants (Table 2). The specific site objectives highlighted the particular reasons each farm was perceived to be a model of sustainability. For example, one farm was identified because it is an outstanding model of how to manage conflicts between agriculture and wildlife. Another farm was considered a superior model of sustainability for its regional marketing efforts. Altering the objectives between farms enabled us to conduct a more comprehensive analysis of various approaches to sustainable farming that captured the differences and similarities in the principles guiding decisionmaking across a broad set of sustainable practices. These objectives provided the initial foundation for the exploration of each case. We worked in small groups of three to four people. Each group reviewed the background information and objectives prior to visiting the individual operation. The groups used the information to develop a set of questions administered in a team-based interview, a technique that has been used by Conlon et al. (2015) to conduct research using grounded theory. The time spent at each farm varied from one to six hours. Interviews were conducted in a group setting and were combined with direct observation of examples of processes, procedures, and practices that the farmers indicated were important for their operations.

Our approach to data analysis was inductive analysis (Bigby, Frawley, \& Radharan, 2014; Borer \& Bowen, 2007; Hammersley, 2011; McMahon \& Fleury, 2012), also sometimes referred to as analytic induction or concept analysis. This approach is closely tied to grounded theory as a discovery research process. Our data analysis process closely resembles what Saldaña (2012) calls analytic induction, in which "answers to research questions are emergently constructed as more and more data are collected and systematically examined" (p. 26). The 
Table 2. Site-specific Learning Objectives Developed To Guide Observations and Team-based Interviews for Each Farm

\begin{tabular}{|c|c|}
\hline Case & Specific Objectives \\
\hline 1 & $\begin{array}{l}\text { - Examine how farmers obtain, evaluate, and use multiple sources of information to develop and adapt } \\
\text { technology and practices to their farming conditions. } \\
\text { - Explore the role of diverse, multidimensional marketing strategies in sustainable farming operations. } \\
\text { - Evaluate the opportunities and barriers that certified organic components create in the management of split } \\
\text { operations. }\end{array}$ \\
\hline 2 & $\begin{array}{l}\text { - Identify and characterize the contribution of farms to community continuity, development, and revitalization. } \\
\text { - Explore the role of farmer-to-farmer collaboration in developing sustainable farming systems. } \\
\text { - Examine how farmers can respond to the limitations and opportunities of location. }\end{array}$ \\
\hline 3 & $\begin{array}{l}\text { - Investigate how farmers respond to changing environmental, policy, and economic climates to create } \\
\text { sustainable agricultural systems. } \\
\text { - Explore the impact of capitalization, infrastructure, and management capacity on farmers' ability to respond to } \\
\text { changing restrictions on and opportunities for agriculture. } \\
\text { - Examine the role of complementarity and multipurposing in creating sustainable agricultural practices and } \\
\text { strategies. }\end{array}$ \\
\hline 4* & $\begin{array}{l}\text { - Examine the role of on-farm innovation in creating sustainable farming systems. } \\
\text { - Explore how farmers identify and develop specialized marketing strategies. } \\
\text { - Analyze the trade-offs between responding to consumer demands and complying with regulatory requirements. }\end{array}$ \\
\hline $5 *$ & $\begin{array}{l}\text { - Examine the role of on-farm innovation in creating sustainable farming systems. } \\
\text { - Explore how farmers identify and develop specialized marketing strategies. } \\
\text { - Analyze the trade-offs between responding to consumer demands and complying with regulatory requirements. }\end{array}$ \\
\hline 6 & $\begin{array}{l}\text { - Analyze how scale of operation affects the role of agriculture in natural resource management and regional } \\
\text { land-use policy. } \\
\text { - Appraise the management capacity and strategies needed for sustainable long-term land-use management. } \\
\text { - Consider the compatibility and role of intensive and extensive production systems in a single farm operation. } \\
\text { - Evaluate how technological change and continuity contribute to sustainable agricultural systems. }\end{array}$ \\
\hline
\end{tabular}

* Sites 4 and 5 had the same site-specific learning objectives due to their proximity to one another.

process included several iterative and cyclical steps as are typical in inductive analysis (Bigby et al., 2014). After each farm visit, the small groups reconvened to reflect on their observations and the information from the interviews individually, share and compare what they had learned, and elaborate and discuss conceptual statements that emerged from the data. The groups tried to identify the ideas or concepts that the farm manager(s) employed to describe and explain their decisionmaking processes for the topics covered in the site objectives. For example, a site objective for one farm was to "examine how farmers obtain, evaluate, and use multiple sources of information to develop and adapt technology and practices to their farming conditions." A key part of inductive analysis is to identify one or more key words or phrases that emerge to describe a condition, process, or action. In this example, we focused on how the farmer describes his or her thinking about on-farm innovation: what it is, the role it plays in keeping the farm going, how she or he considers and compares different potential innovations directed to improve the farming system.

The group members then used their own prior knowledge and experience with sustainable agriculture and the concepts that had emerged through other cases to examine how the farmer's practices or approaches are related to sustainable agriculture to achieve collaborative results (Saab, van Joolingen, \& van Hout-Wolters, 2005). Once the group members had exhausted their ability to identify specific instances of the ways an approach is used or implemented, they tried to create a higher order or broader concept that was applicable beyond the case, in this example a general concept about the role of innovation that can be applied more generally to inform the practice of 
sustainable agriculture. At the end of each day, the entire large group discussed similarities and differences observed in the operations visited that day and discussed, criticized, and refined-or abandoned - the higher-level conceptualizations that had emerged as a result of the day's work.

On the last day we examined all of the broad concepts identified in the small groups. We identified shared concepts to emphasize the key ideas, while. eliminating some concepts from further consideration when participants felt that the concept was too narrow to address our objective of identifying common principles guiding sustainable decision-making. As the concepts were refined, combined into more inclusive concepts, or rejected, a final set of proposed principles of sustainable agriculture emerged.

The results of the inductive analysis consist of the identification of key ideas that are shared by several, or sometimes all, of the farmers or that are repeatedly stressed or emphasized by respondents. We identified nine key themes or ideas and explored how the themes are expressed in the different farm operations. The nine principles of sustainable agriculture are presented in the Appendix. We use examples from our sample to exemplify each principle in the presentation of results.

The principles that we identified are not intended as "rules" or absolutes. The principles are best conceived as components of an emerging model of "how farmers create sustainable agriculture," the kind of qualitative model that Northcutt $\&$ McCoy (2004) propose as a higher order level of qualitative data analysis that approaches explanation. We also see these principles as hypothetical statements about the norms and values that underlie farmers' "everyday practice of sustainable agriculture," that could be subjected to testing, corroboration, or disproof as hypotheses. The nine principles are listed in Table 3.

\section{Results}

\section{Change}

The farmers said that they continuously face new challenges in their operations, requiring them to adapt key aspects of their operations from

\section{Table 3. Nine Generalizable Principles of Sustainable Agriculture Guiding Farmers' Decision-Making} Regarding Their Operations

\section{Principles of Sustainable Agriculture}

1. Sustainable farmers anticipate change-they recognize, accept, plan for, and create change.

2. Sustainable farmers recognize and identify limitations and resources and create a strategy to develop their resources and to minimize and overcome limitations.

3. Sustainable farmers build strong, mutually beneficial relationships with individuals, institutions, and organizations based on a sense of responsibility to the community and the need to give back to the community.

4. Sustainable farmers invest in their employees to create a loyal, dedicated, and engaged workforce that shares responsibility for the success of the farming operation.

5. Sustainable farmers are not satisfied with average business practices or products; high quality characterizes every component of their businesses.

6. Sustainable farming operations are management-intensive, distribute responsibility and decision-making among all employees, draw upon diverse skill sets in management, and integrate management functions and decisions across the farm operation.

7. Sustainable farms are businesses first and foremost, but profits are used to both grow the business and address broader social and environmental goals.

8. Sustainable farmers take appropriate risks, incur reasonable debt, and make investments based on mid- to long-term challenges and opportunities.

9. Sustainable farmers have a passion for farming reflected in their dedication, integrity, and honesty as professionals, but their passion is practical because they understand that the success of the business makes it possible to pursue their passion. 
production to marketing and finances to fit changing circumstances. All six operators indicated they expect many changes in agriculture in the future, but the kinds of changes they envisioned varied. Some of the changes they mentioned were new regulations, decreasing or increasing consumer demand, fluctuating market prices, and inevitable natural forces like weather. For example, several farmers mentioned regulatory changes, but their strategies for addressing new regulations varied. One farmer chose to implement a management strategy now to address these coming changes. Some examples of change were very specific to local conditions. Soil oxidation is a constant concern for growers in south Florida who farm on organic soils (having a high percent of organic matter, e.g. 10 percent) because these soils oxidize (or "subside") when drained. The soil can lose up to an inch $(2.5 \mathrm{~cm})$ of top soil each year, ultimately leaving the farmer with bare limestone (Wright \& Snyder, 2009). Only one farmer cited this particular form of change, but he, too, sought a strategic approach, to adopt farming practices that will minimize soil oxidation and maintain or improve existing soil conditions. Thinking about and planning for change rather than ignoring change was a common thread in farmers' comments.

Principle \#1: Sustainable farmers anticipate changethey recognize, accept, plan for, and create change.

\section{Limitations and Resources}

The kinds of limitations of and resources available to their operations were clearly recognized by these farmers. These were universal in some senses-all farms need land and capital-but the degree to which each operation faced a specific set of limitations and called upon a unique set of human, environmental, and fiscal resources was very revealing about the diversity of these farms. Every farmer identified resource limitations, ranging from capital to water to skilled labor. These farmers clearly voiced the need to make the best use of any limited resource. They discussed how they use existing resources, such as financial support or new technologies, to contribute to the success of their businesses. They tended to view the contemporary environment as one of increasingly limited resources and growing competition, and articulated the idea that failure to make good use of resources can be fatal. For example, one farmer recognized that she could not manage her small poultry operation effectively by herself. She recruited local individuals who shared her passion and vision for locally raised poultry to assist on the farm and at markets. Another livestock producer recognized that his strength lies in breeding. His operation ships steers to operations in other states that specialize in finishing steers rather than trying to raise finished animals.

Principle \#2: Sustainable farmers recognize and identify limitations and resources and create strategies to develop their resources and minimize and overcome limitations.

\section{Relationships}

All six farm operators recognized that their farms are not isolated from non-farm (non-agricultural) people, businesses, and organizations in the communities around them, rural or urban. They knew that their relationship to the residents of the communities where they operate affects their operations, and they expressed a sense of responsibility to their community. Four of the six mentioned specific ways in which they integrate themselves into surrounding communities, and expressed the need to ensure that community residents realize that farms are a valuable asset to the community as a whole. This perspective focused on the total contribution that farms can make to a community, including giving back to the community. For example, a farm in the study actively participates in its local community by providing support to various grassroots organizations addressing education, wildlife, environment, and literacy. Another farm reaches beyond its immediate local community and is very well connected to its regional community. The operators open the farm to guests several times a month for a farm-to-fork dinner and donate the proceeds to various local charities. Another operation donates unsold or short-dated products to food banks and community groups.

Principle \#3: Sustainable farmers build strong, mutually beneficial relationships with individuals, institutions, and organizations based on a sense of responsibility to their community and the need to give back to their community. 


\section{Human Resources}

Employees were a critical asset to and component of the success of these farms. All the operators cited the importance of fostering an environment that enhances the work experience for their employees, including but not limited to financial rewards. For example, several farmers said that providing opportunities for employees to participate in decision-making about issues related to both operational and individual needs increases their employees' satisfaction. One farm responded to the needs of employees by ending their volunteer labor recruitment in order to enable paid employees to dedicate more time to their own interests on the farm rather than training and supervising volunteers. Employees at one farm receive professional development incentives and are provided with opportunities to advance within the company. All employees at every farm received livable wages and benefits. Benefits were not limited to traditional benefits like health insurance or retirement plans. Some farms offered benefits like transportation, housing, or a share of the products raised on the farm. For these farmers, employees were a critical key to success.

Principle \#4: Sustainable farms invest in their employees to create a loyal, dedicated, and engaged workforce that shares responsibility for the success of the farming operation.

\footnotetext{
Quality

"Quality" was a word that emerged time after time in this study. A summative statement that illustrates what we heard was that "mediocre businesses that produce mediocre products are unlikely to prosper." The degree to which concerns for quality drive these farmers' decisions and practices was clear, and it was also clear that they saw quality as a key to a successful and sustainable business operation. Each farm we visited was proud to produce a premium product. While many farmers focus on keeping their product prices "competitive," five of the six farmers in this study were proud to make a high-quality product that sells for a premium price. They have worked to create a loyal customer base that appreciates the value of the high-quality products they offer. They have identified markets that appreciate and demand high-quality products. In some cases this was accomplished by establishing
}

relationships with high-end purchasers, such as membership-only clubs and five-star restaurants. They also met or exceeded certification criteria and provided high-quality training for employees. The farmers in this study were not content until they felt their practices and products met their own and their customers' expectations, and they continually strive to improve their products.

Principle \#5: Sustainable farmers are not satisfied with average business practices or products; high quality characterizes every component of their business.

\section{Management}

From the largest to the smallest operations, these farmers stress that management is a critical key to success in contemporary social and business environments. This was closely related to the importance of human resources. They view encouraging people to accomplish the farm's goals and objectives using available resources in an efficient and effective manner as central to a successful management plan. They use many techniques to improve management. Some allocate responsibility to key individuals at different stages of production to make use of individual strengths and maximize efficiency. Several stressed the need to have clear and precise operating procedures and expectations in order to help deal with problems and address issues before they become a problem. For example, one of the larger farms we visited divided the operation into smaller units managed by independent teams. Individual units were self-sufficient and able to make critical decisions, provided they complied with some standard farm operating procedures. Perhaps surprising, the same management technique was also used at several of the smaller farms. Employees were given freedom to make independent decisions and implement their ideas as long as they fit within the overall vision of the farm. Principle \#6: Sustainable farming operations are management-intensive, distribute responsibility and decisionmaking among employees, draw upon diverse skill sets in management, and integrate management functions and decisions across the farm operation.

\section{A Farm Is a Business}

While these farmers clearly had a love and passion for the land and for farming, they also clearly 
understood that economic success and growth were prerequisites for sustainability. A clear theme was that economic success is not "just to make money," but rather is seen as a precondition to investing in many aspects of the farm as a business, a resource, and a home, and to permitting farmers, their families, and their employees to pursue their own personal interests within the context of the farm business plan. For example, all the farmers in our study discussed reinvesting capital into their operation to improve their efficiency or offer a new product. One farmer used profits to improve environmental conditions on his property and positively contribute to his community by devoting a third of his land to wildlife conservation. This farmer has also developed and implemented a plan to improve the quality of the water that leaves the farm and is used by neighboring communities. Nonetheless, all of these farmers clearly run their farms first and foremost as businesses because the success of the business is what allows them to pursue other personal and social goals.

Principle \#7: Sustainable farms are businesses first and foremost, but profits are used to grow the business and to address broader social and environmental goals.

\section{Planning}

The farmers we interviewed were "planners," and they plan for the long term. They could articulate clear goals for their farms with timelines. Some of their comments associated these long-term goals with a framework within which decisions about investments and opportunities are made. One of the farmers adjusted his or her long-standing marketing approach to reduce economic risks in the increasingly volatile global marketplace. The farm now only grows those products that can be grown under contract with specific trusted buyers and will only work with buyers who pay the market price at the time of shipment. Another operator planned to offer new products to ensure that returning customers find variety. One farmer stressed the importance of making smart investments, such as purchasing new equipment that would allow her to diversify her operation and increase profits. Although small farmers are often described as "risk adverse" and "unwilling to assume debt," she is just one of the small farmers in this group who chose to take a financial risk. She purchased new equipment using a small farm loan because she saw an opportunity for her business to offer a new product no one else in the area was providing. These farmers were "fiscally conservative," but not risk avoiders.

Principle \#8: Sustainable farmers take appropriate risks, incur reasonable debt, and make investments based on mid- to long-term challenges and opportunities.

\section{Passion}

All these farmers expressed the saying that "you'll never work a day in your life if you love what you do." These farmers viewed themselves as "professionals in farming" and all of them talked about their work as a passion—not a job. Producing a high-quality product that they could offer with pride was important, but for all of these businesspeople the product was only one important component of his or her "work." Every one of them valued his or her connection to the environment and community. But they also stressed that you have to be "practical." They saw being practical and prudent as keys to the success of their businesses, and for them their businesses are the pathway to do what they love.

Principle \#9: Sustainable farmers have a passion for farming reflected in their dedication, integrity, and honesty as professionals, but their passion is practical because they understand that the success of the business makes it possible to pursue their passion.

\section{Discussion}

In the introduction to this article we referred to the ongoing debate about the degree to which sustainable agriculture necessarily requires a major shift in the values, theories, and assumptions underlying post-WWII agricultural science. This is by far the most commonly articulated debate in the sustainable agriculture literature and currently tends to center on the concepts of ecological or agroecological agriculture versus sustainable intensification.

Our research suggests that the distinctions drawn between the agro-ecological and sustainable intensification proponents may not be nearly as clear for farmers trying to practice sustainable agriculture as the literature would suggest. While 
the importance of profitability is clearly reflected in Principles 5, 7, and 8, a deep concern for the environment is reflected in several principles, including these same principles. These businesspeople tended to tie profitability and environmental protection together and described using their profits to support environmental organizations and causes and to take steps to protect and enhance resources both on the farm and off. Principle 7 reflects this blending: Sustainable farms are businesses first and foremost, but profits are used to grow the business and to address broader social and environmental goals. Although there were certainly philosophical differences in their worldviews and goals for their enterprises, and some were organic producers and some not, they shared basic values related to environmental protection and resource conservation.

There are at least two other critical components of the discussion about how much and what kinds of change are required to achieve sustainable agriculture. One is the equally vibrant discussion about the economics of sustainability, and by implication the economics of sustainable agriculture. Just as there are two strongly contrasting views about the environmental requirements for sustainable agriculture, the economic debate tends to reflect two quite different concepts of what a "sustainable economy" demands (Baumgärtner, \& Quaas, 2010; Illge \& Schwarze, 2009). Although there are other perspectives, the two economic perspectives can be described as the degrowth and the green economy schools. The degrowth approach (or the less restrictive no growth approach) to the economics of sustainability argues that further economic growth is detrimental to the environment because growth of any sort implies a greater throughput of energy and materials (Kallis, 2011; Kallis, Kerschner, \& Martinez-Alier, 2012). Some proponents of degrowth also point to the social benefits of a degrowth economy (Andreoni \& Galmarini, 2013; Johanisova, Crabtree \& Franková, 2013). Although not yet prevalent in the sustainable agriculture literature, the degrowth perspective underlies the critique of capitalist economics and the role of profitability in the beyond organic movement (Martínez-Alier, Pascual, Vivien, \& Zaccai, 2010; Sekulova, Kallis,
Rodríguez-Labajos, \& Schneider, 2013; Sorman \& Giampietro, 2013). In contrast, the "greening the economy" approach argues for incorporating environmental accounting into classic economic measures to achieve sustainable economic performance and growth (Bartelmus, 2010). Proponents of greening the economy address policy, governance, and investment components of a green economy (Graham \& Bertels, 2008; Gupta \& Sanchez, 2012; Martins, 2013; Meléndez-Ortiz, 2011) and more operational considerations like green jobs and sustainable consumption (Akenji, 2014; Cai, Wang, Chen, \& Wang, 2011; Seyfang \& Longhurst, 2013; Tiley \& Young, 2009). Although better represented in the sustainable agriculture literature than the degrowth perspective, direct application of the key concepts of the green economy approach have not been addressed.

The principles that emerged in our analysis show little relationship between these managers' concepts of sustainable economics and the concept of degrowth-or even no growth. On the contrary, all but one of the managers saw economic growth as a positive and desirable outcome for their businesses. On the other hand, almost all the respondents did describe parts of their business models that reflect key ideas in the green economy literature. Examples were cited in our discussions of Principles 3, 4, 8, and 9. Perhaps most congruent with the concept of greening the economy is the strong relationship between growth and investment in human and environmental resources that was a focus for most of these managers. Overall, our results suggest that some of the key concepts of greening the economy, particularly as they relate to a broader range of economic goals than profitability alone, are key factors in these entrepreneurs' decision-making.

Finally, there is a rather poorly defined controversy about the social requirements for a sustainable food and agriculture system. The social requisites for sustainability in general have received much less attention than the environmental and economic components, and the distinctions between alternative approaches to social sustainability are not nearly as well defined as those of environmental and economic sustainability. From a farm policy perspective, much of the discussion of 
the social component of sustainable agriculture has revolved around meeting the needs of small farmers and the economic health of rural communities (Ashwood, Diamond, \& Thu, 2014; Hamilton, 2014; Kirner \& Kratochvil, 2006; Pilgeram, 2011; Reinhardt \& Barlett, 1989; Tavernier \& Tolomeo, 2004; Woodhouse, 2010). However, a broader agenda of food and agriculture-related issues also exists and is perhaps growing in importance. There are two distinct approaches to the social aspects of sustainability that are directly relevant to sustainable agriculture: social justice and sustainable or ethical consumerism.

The increase of food insecurity in the United States and globally, including lack of access to safe, affordable, healthy food, is now a greater concern to a wider audience of researchers and practitioners. There is growing emphasis on the relationships between social justice and sustainable agriculture and how the objectives associated with each can be complementary (Ayres \& Bosia, 2011; Connelly, Markey \& Roseland, 2011; Hernandez \& Pressler, 2013; Johnston, 2008; Mandell, 2009; Masters, Krogstrand, Eskridge, \& Albrecht, 2014; MinkoffZern, 2014). At a more regional level, concerns about the potential for the local and organic food movement to increase social divisions through unequal access to venues like farmers' markets have grown (Agyeman, 2005; Alkon, 2008, 2013; Deutsch, 2011). The degree to which elite-serving value chains exacerbate social injustice globally by allowing practices like child labor or driving agricultural production for export to the U.S. and Europe instead of meeting food needs at home is now part of the sustainable agriculture agenda (Berlan, 2013; Bolwig, Ponte, du Toit, Riisgaard, \& Halberg, 2010). Attention has also turned to the impacts of the conventional food production system on farm laborers and their families (Dorward, 2013; Fridell, 2007; Wilson \& Curnow, 2013) and on rural communities globally (Crowell \& Sligh, 2006; Meléndez-Ortiz, 2011; Wilkinson, 2009; Varul, 2008). Others have focused on gender and ethnic disparities in both natural resource conservation and destruction (Brady \& Monani, 2012; Hecht, 2007; Robinson, 2011). There is an emerging consensus among these researchers that deeply embedded social and economic structures create and propagate these disparities, that these structures are globally systemic, and that the traditional emphases on environmental and economics in sustainable agriculture will not address these issues.

These concerns are not irrelevant to those who propose sustainable or ethical consumerism as a key to sustainable agriculture, but the emphases are certainly different. The key concepts of sustainable (or ethical) consumerism are well reflected in the sustainable agriculture movement and have been for many years (Fernandez, Goodall, Olson, \& Méndez, 2013; Smaje, 2014). These concepts underlie much of the emphasis on alternative marketing. Purchasing organic, local foods through community supported agriculture operations (CSAs), farmers markets, and consumer cooperatives are all considered ways to express ethical consumerism and support sustainable agriculture (Cairns et al., 2013; Crivits \& Paredis, 2013). Various certification schemes such as "just food" and "fair trade" are seen by many as fundamental to global sustainable agriculture (Cailleba \& Casteran, 2010; Hutchins \& Sutherland, 2008; Wilson \& Curnow, 2013; Zander \& Hamm, 2010). Nonetheless, there are dissenting voices that raise concerns about the efficacy and perhaps even the desirability of these approaches (Akenji, 2014; Fridell, 2007; Irvine, 2013; Johnston, 2008; Varul, 2008).

Our results show that the farmers and managers we interviewed recognize both social justice and ethical consumerism as important components of sustainable agriculture. The support provided by ethnical consumerism was mentioned repeatedly as a key component in both the success of these businesses and in the managers' approaches to managing their businesses. This was true for organic and conventional operations, large and small businesses, and operations relying on both conventional and alternative marketing approaches. The universal importance of ethical consumers willing to pay for quality products and loyal to the producers of those products for virtually all of these businesses was surprising. The common wisdom is that the strong consumer-producer tie is primarily a phenomenon for organic producers and consumers 
or for producers and consumers who share alternative, nontraditional markets. Our results suggest that this is not true, and instead that the role of ethical consumerism is critical to sustainable farms and enterprises of all sorts. This concept was reflected in several of the key principles that emerged: principles $2,3,5,7$, and 8. Simply put, the values and norms of consumers were key to the principles on which these businesses operate. Another common farm value is that almost all of these businesses also incorporate key aspects of social justice in their operations, reflected particularly in the ways employees are valued, recognized, and supported (Principles 1, 2, 4, and 6) and in the strong commitment to local communities that many of these businesses have made (Principles 3, 7, and 9).

The common denominator among the businesses that we chose for the SARE Fellows program case study was that all were considered to provide good examples of sustainable agriculture in practice by professionals in the field. Among the businesses nominated for our program, we purposefully selected a sample of businesses representing a wide range of characteristics with regard to size, enterprise mix, conventional vs. organic production systems, and marketing strategies. Despite these differences, these operations shared many principles that inform their decision-making about both the day-to-day and long-term operation of their businesses. The degree to which these principles incorporate key ideas about the environmental, social, and economic components of sustainability varies. Nonetheless, most of the contemporary theoretical concepts about environmental, social, and economic sustainability are reflected in the operating principles of these businesses. This suggests that these principles are relevant for the practice of sustainable agriculture. We encourage other researchers to further explore the generalizability of our conclusions by examining the degree to which these principles are expressed in other contexts. For example, our research did not explore other contextual factors such as the political landscape, the recent recession, and natural disasters that could also affect farmers' decision-making and may be reflected in the principles that emerged. Comparisons of the degree to which agricultural businesses that are considered good examples of sustainability to those who are less involved in sustainable agriculture would be also be very useful.

\section{References}

Abrams, L. S. (2010). Sampling 'hard to reach' populations in qualitative research: The case of incarcerated youth. Qualitative Social Work, 9(4), 536-550. http://dx.doi.org/10.1177/1473325010367821

Agyeman, J. (2005). Alternatives for community and environment: Where justice and sustainability meet. Environment, 47(6), 10-23. http://dx.doi.org/10.3200/ENVT.47.6.10-23

Akenji, L. (2014). Consumer scapegoatism and limits to green consumerism. Journal of Cleaner Production, 63, 13-23. http://dx.doi.org/10.1016/j.jclepro.2013.05.022

Albaho, M., Thomas, B., \& Christopher, A. (2008). Evaluation of hydroponic techniques on growth and productivity of greenhouse grown bell pepper and strawberry. International Journal of $V$ egetable Science, 14(1), 23-40. http://dx.doi.org/10.1080/19315260801890492

Albajes, R., Cantero-Martínez, C., Capell, T., Christou, P., Farre, A., Galceran, J.,... Voltas, J. (2013). Building bridges: An integrated strategy for sustainable food production throughout the value chain. Molecular Breeding, 32(4), 743-770. http://dx.doi.org/10.1007/s11032-013-9915-Z

Alkon, A. (2008). Paradise or pavement: The social constructions of the environment in two urban farmers' markets and their implications for environmental justice and sustainability. Local Environment, 13(3), 271-289. http://dx.doi.org/10.1080/13549830701669039

Alkon, A. H. (2013). The socio-nature of local organic food. Antipode, 45(3), 663-680. http://dx.doi.org/ 10.1111/i.1467-8330.2012.01056.x

Altieri, M. A. (1989). Sustainable agriculture: Overview. Environment, 31(3), 2-3.

Altieri, M. A., \& Rosset, P. (1996). Agroecology and the conversion of large-scale conventional systems to sustainable management. International Journal of Environmental Studies, 50(3-4), 165-185. http://dx.doi.org/10.1080/00207239608711055 
Amsteus, M. N. (2014). The validity of divergent grounded theory method. International Journal of Qualitative Methods, 13, 71-87. Retrieved from https:// ejournals.library.ualberta.ca/index.php/ IJQM/article/view/18938

Andreoni, V., \& Galmarini, S. (2013). On the increase of social capital in degrowth economy. Procedia, 72, 64-72.

http://dx.doi.org/10.1016/j.sbspro.2013.02.006

Ashwood, L., Diamond, D., \& Thu, K. (2014). Where's the farmer? Limiting liability in Midwestern industrial hog production. Rural Sociology, 79(1), 2-27. http://dx.doi.org/10.1111/ruso.12026

Auerswald, C. L., Greene, K., Minnis, A., Doherty, I., Ellen, J., \& Padian, N. (2004). Qualitative assessment of venues for purposive sampling of hard-to-reach youth: An illustration in a Latino community. Sexually Transmitted Diseases, 31(2), 133-138. http://dx.doi.org/10.1097/01.OLQ. 0000109513.30732.B6

Ayres, J., \& Bosia, M. J. (2011). Beyond global summitry: Food sovereignty as localized resistance to globalization. Globalizations, 8(1), 47-63. http://dx.doi.org/10.1080/14747731.2011.544203

Balmford, A., Green, R. E., \& Scharlemann, J. P. W. (2005). Sparing land for nature: Exploring the potential impact of changes in agricultural yield on the area needed for crop production. Global Change Biology, 11(10), 1594-1605. http://dx.doi.org/ 10.1111/j.1365-2486.2005.001035.x

Balwinder-Singh, Humphreys, E., Gaydon, D. S., \& Sudhir-Yadav. (2015). Options for increasing the productivity of the rice-wheat system of north west India while reducing groundwater depletion. Part 2. Is conservation agriculture the answer? Field Crops Research, 173, 81-94. http://dx.doi.org/10.1016/i.fcr.2014.11.019

Barbier, E. B. (1989). Sustaining agriculture on marginal land: A policy framework. Environment, 31(9), 12-40.

http://dx.doi.org/10.1080/00139157.1989.9928979

Barnes, A. P., \& Thomson, S. G. (2014). Measuring progress towards sustainable intensification: How far can secondary data go? Ecological Indicators, 36, 213-220. http://dx.doi.org/10.1016/j.ecolind.2013.07.001
Bartelmus, P. (2010). Use and usefulness of sustainability economics. Ecological Economics, 69(11), 2053-2055.

http://dx.doi.org/10.1016/j.ecolecon.2010.06.019

Baumgärtner, S., \& Quaas, M. (2010). What is sustainability economics? Ecological Economics, 69(3), 445-450.

http://dx.doi.org/10.1016/j.ecolecon.2009.11.019

Bellows, A. C., Alcaraz V., G., \& Hallman, W. K. (2010). Gender and food, a study of attitudes in the USA towards organic, local, U.S. grown, and GM-free foods. Appetite, 55(3), 540-550. http://dx.doi.org/10.1016/j.appet.2010.09.002

Bennett, A. B., Chi-Ham, C., Barrows, G., Sexton, S., \& Zilberman, D. (2013). Agricultural biotechnology: Economics, environment, ethics, and the future. Annual Review of Environment and Resources, 38, 249_ 279. http://dx.doi.org/10.1146/annurev-environ050912-124612

Berkhout, F. (2002). Novel foods, traditional debates: Framing biotechnology sustainability. New Genetics and Society, 21(2), 131-148. http://dx.doi.org/10.1080/1463677022000006989

Berlan, A. (2013). Social sustainability in agriculture: An anthropological perspective on child labour in cocoa production in Ghana. The Journal of Development Studies, 49(8), 1088-1100. http://dx.doi.org/10.1080/00220388.2013.780041

Berry, W. (2000). Life is a miracle: An essay against modern superstition. Berkeley, California: Counterpoint Press.

Bigby, C., Frawley, P. \& Radharan, P. (2014). A collaborative group method of inclusive research. Journal of Applied Research in Intellectual Disabilities, 27(1), 54-64. http://dx.doi.org/10.1111/jar.12082

Bisht, I. S., Pandravada, S. R., Rana, J. C., Malik, S. K., Singh, A., Singh, P. B.,...Bansal, K. C. (2014). Subsistence farming, agrobiodiversity, and sustainable agriculture: A case study. Agroecology and Sustainable Food Systems, 38(8), 890-912. http://dx.doi.org/10.1080/21683565.2014.901273

Bolwig, S., Ponte, S., du Toit, A., Riisgaard, L., \& Halberg, N. (2010). Integrating poverty and environmental concerns into value-chain analysis: A conceptual framework. Development Policy Review, 28(2), 173-194. http://dx.doi.org/10.1111/j.14677679.2010.00480.x 
Bonaudo, T., Bendahan, A. B., Sabatier, R., Ryschawy, J., Bellon, S., Leger, F.,...Tichit, M. (2014). Agroecological principles for the redesign of integrated crop-livestock systems. European Journal of Agronomy, 57, 43-51. http://dx.doi.org/10.1016/i.eja.2013.09.010

Boogaard, B. K., Oosting, S. J., \& Bock, B. B. (2008). Defining sustainability as a socio-cultural concept: Citizen panels visiting dairy farms in the Netherlands. Livestock Science, 117(1), 24-33. http://dx.doi.org/10.1016/j.livsci.2007.11.004

Borer, D. A., \& Bowen, J. D. (2007). Rethinking the Cuban embargo: An inductive analysis. Foreign Policy Analysis, 3(2), 127-143. http://dx.doi.org/ 10.1111/j.1743-8594.2007.00044.x

Brady, M. J., \& Monani, S. (2012). Wind power! Marketing renewable energy on tribal lands and the struggle for just sustainability. Local Environment, 17(2), 147-166. http://dx.doi.org/10.1080/13549839.2011.646966

Brasier, K. J. (2005). Spatial analysis of change in the number of farms during the farm crisis. Rural Sociology, 70(4), 540-560. http://onlinelibrary. wiley.com/journal/10.1111/\%28ISSN \%291549$\underline{0831}$

Cailleba, P., \& Casteran, H. (2010). Do ethical values work? A quantitative study of the impact of fair trade coffee on consumer behavior. Journal of Business Ethics, 97(4), 613-624. http://dx.doi.org/10.1007/s10551-010-0528-8

Cai, W., Wang, C., Chen, J., \& Wang, S. (2011). Green economy and green jobs: Myth or reality? The case of China's power generation sector. Energy, 36(10), 5994-6003.

http://dx.doi.org/10.1016/j.energy.2011.08.016

Cairns, K., Johnston, J., \& MacKendrick, N. (2013). Feeding the 'organic child': Mothering through ethical consumption. Journal of Consumer Culture, 13(2), 97-118. http://dx.doi.org/10.1177/1469540513480162

Ceddia, M. G., Bardsley, N. O., Gomez-y-Paloma, S., \& Sedlacek, S. (2014). Governance, agricultural intensification, and land sparing in tropical South America. Proceedings of the National Academy of Sciences of the United States of America, 111(20), 7242-7247. http://dx.doi.org/10.1073/pnas.1317967111

Cerutti, A. K., Beccaro, G. L., Bagliani, M., Donno, D., \& Bounous, G. (2013). Multifunctional ecological footprint analysis for assessing eco-efficiency: A case study of fruit production systems in northern Italy. Journal of Cleaner Production, 40, 108-117. http://dx.doi.org/10.1016/j.jclepro.2012.09.028

Conlon, C., Carney, G., Timonen, V., \& Scharf, T. (2015). 'Emergent reconstruction' in grounded theory: Learning from team-based interview research. Qualitative Research, 15(1), 39-56. http://dx.doi.org/10.1177/1468794113495038

Connelly, S., Markey, S., \& Roseland, M. (2011). Bridging sustainability and the social economy: Achieving community transformation through local food initiatives. Critical Social Policy, 31(2), 308-324. http://dx.doi.org/10.1177/0261018310396040

Cornes, S. (2011). The agrarian vision: Sustainability and environmental ethics, by Paul B. Thompson. Journal of Sustainable Agriculture, 35(2), 235-239. http://dx.doi.org/10.1080/10440046.2011.539140

Cox, T. E. B. (2014). Transpersonal agroecology: The metaphysics of alternative agricultural theory. Journal of Transpersonal Psychology, 46(1), 35-57. Available at http://www.atpweb.org/jtparchive/ trps-46-14-01-035.pdf

Crivits, M., \& Paredis, E. (2013). Designing an explanatory practice framework: Local food systems as a case. Journal of Consumer Culture, 13(3), 306-336. http://dx.doi.org/10.1177/1469540513484321

Cross, P., Edwards, R. T., Opondo, M., Nyeko, P., \& Edwards-Jones, G. (2009). Does farm worker health vary between localised and globalised food supply systems? Environment International, 35(7), 1004-1014. http://dx.doi.org/10.1016/i.envint.2009.04.009

Crowe, S., Cresswell, K., Robertson, A., Huby, G., Avery, A., \& Sheikh, A. (2011). The case study approach. BMC Medical Research Methodology, 11, 100-108. http://dx.doi.org/10.1186/1471-2288$\underline{11-100}$

Crowell, E., \& Sligh, M. (2006). Domestic fair trade: For health, justice \& sustainability. Social Policy, 37(1), 5-8.

Curtis, S., Gesler, W., Smith, G., \& Washburn, S. (2000). Approaches to sampling and case selection in qualitative research: Examples in the geography of health. Social Science and Medicine, 50(7-8), 10011014. http://dx.doi.org/10.1016/S0277$\underline{9536(99) 00350-0}$ 
Dahlberg, K. A. (1991). Sustainable agriculture-fad or harbinger? BioScience, 41(5), 337-340. http://dx.doi.org/10.2307/1311588

Darnhofer, I., Lindenthal, T., Bartel-Kratochvil, R., \& Zollitsch, W. (2010). Conventionalisation of organic farming practices: From structural criteria towards an assessment based on organic principles. A review. Agronomy for Sustainable Development, 30(1), 67-81. http://dx.doi.org/10.1051/agro/2009011

Davies-Jones, A. (2011). Implementing sustainable development for the countryside: A case study of agri-envronment reform in Wales. Environmental Law Review, 13(1), 9-24. http://dx.doi.org/10.1350/enlr.2011.13.1.110

del Amor, F. M., López-Marin, J., \& González, A. (2008). Effect of photoselective sheet and grafting technique on growth, yield, and mineral composition of sweet pepper plants. Journal of Plant Nutrition, 31(6), 1108-1120. http://dx.doi.org/10.1080/01904160802115557

Delgado, J. A., \& Berry, J. K. (2008). Advances in Precision Conservation. Advances in Agronomy, 98, 1-44. http://dx.doi.org/10.1016/S00652113(08)00201-0

Deutsch, T. (2011). Memories of mothers in the kitchen: Local foods, history, and women's work. Radical History Review, 110, 167-177. http://dx.doi.org/10.1215/01636545-2010-032

Dobrovolski, R., Loyola, R. D., Guilhauman, F., Gouveia, S. F., \& Diniz-Filho, J. A. F. (2013). Global agricultural expansion and carnivore conservation biogeography. Biological Conservation, 165, 162-170.

http://dx.doi.org/10.1016/j.biocon.2013.06.004

Dogliotti, S., García, M. C., Peluffo, S., Dieste, J. P., Pedemonte, A. J., Bacigalupe, G. F.,...Rossing, W. A. H. (2014). Co-innovation of family farm systems: A systems approach to sustainable agriculture. Agricultural Systems, 126, 76-86. http://dx.doi.org/10.1016/j.agsy.2013.02.009

Doré, T., Makowski, D., Malézieux, E., Munier-Jolain, N., Tchamitchian, M., \& Tittonell, P. (2011). Facing up to the paradigm of ecological intensification in agronomy: Revisiting methods, concepts and knowledge. European Journal of Agronomy, 34(4), 197210. http://dx.doi.org/10.1016/j.eja.2011.02.006
Dorward, A. (2013). Agricultural labour productivity, food prices and sustainable development impacts and indicators. Food Policy, 39, 40-50. http://dx.doi.org/10.1016/i.foodpol.2012.12.003

Duffy, M. (2014). 2013 farmland value survey (File C2-70). Retrieved May 30, 2014, from http://www.exten sion.iastate.edu/agdm/wholefarm/pdf/c2-70.pdf

Edwards, C. A., Grove, T. L., Harwood, R. R., \& Colfer, C. J. P. (1993). The role of agroecology and integrated farming systems in agricultural sustainability. Agriculture, Ecosystems, and Environment, 46(1-4), 99-121. http://dx.doi.org/10.1016/01678809(93)90017-J

Elliott, J., \& Firbank, L. (2013). Sustainable intensification: A case for innovation in science and policy. Outlook on Agriculture, 42(2), 77-80. http://dx.doi.org/10.5367/oa.2013.0124

Engward, H. (2013). Understanding grounded theory. Nursing Standard, 28(7), 37-41. http://dx.doi.org/ 10.7748/ns2013.10.28.7.37.e7806

Entz, M. (2015). Fixing food: Ecological agriculture is chicken soup for the soil. Alternatives Journal, 41(1), 26-28. Retrieved from http://www.alternatives journal.ca/science-and-solutions/fixing-canadasfood-system

Faeth, P. (1992). Building the case for sustainable agriculture. Environment, 36(1), 16-20.

Fautin, D. G. (1995). Sustainability-More than a buzzword? Annual Review of Ecology and Systematics, 26, vx. http://dx.doi.org/10.1146/annurev.es.26. $\underline{090506.100001}$

Ferguson, R. S., \& Lovell, S. T. (2014). Permaculture for agroecology: Design, movement, practice and worldview. A review. Agronomy for Sustainable Development, 34(2), 251-274. http://dx.doi.org/10.1007/s13593-013-0181-6

Fernandes, L. A. O., \& Woodhouse, P. J. (2008). Family farm sustainability in southern Brazil: An application of agri-environmental indicators. Ecological Economics, 66(2-3), 243-257. http://dx.doi.org/10.1016/j.ecolecon.2008.01.027

Fernandez, M., Goodall, K., Olson, M., \& Méndez, V. E. (2013). Agroecology and alternative agri-food movements in the United States: Toward a sustainable agri-food system. Agroecology and Sustainable Food Systems, 37(1), 115-126. http://dx.doi.org/10.1080/10440046.2012.735633 
Fish, R., Winter, M., \& Lobley, M. (2014). Sustainable intensification and ecosystem services: New directions in agricultural governance. Policy Sciences, 47(1), 51-67. http://dx.doi.org/10.1007/s11077013-9183-0

Fix, W. (1995). Toward a transpersonal ecology: Developing new foundations for environmentalism. New York: State University of New York Press.

Flavell, R. (2010). Knowledge and technologies for sustainable intensification of food production. New Biotechnology, 27(5), 505-516. http://dx.doi.org/10.1016/j.nbt.2010.05.019

Fridell, G. (2007). Fair-trade coffee and commodity fetishism: The limits of market-driven social justice. Historical Materialism, 15(4), 79-104. http://dx.doi.org/10.1163/156920607X245841

Friend, J. A. (1990). Defining sustainable agriculture. Social Alternatives, 9(3), 8-12.

Gaurav, S., \& Mishra, S. (2015). Farm size and returns to cultivation in India: Revising an old debate. Oxford Development Studies, 43(2), 165-193. http://dx.doi.org/10.1080/13600818.2014.982081

Girard, N., Magda, D., Noseda, C., \& Sarandon, S. (2015). Practicing agroecology: Management principles drawn from small farming in Misiones (Argentina). Agroecology and Sustainable Food Systems, 39(7), 824-840.

http://dx.doi.org/10.1080/21683565.2015.1020081

Glaser, B. G., \& Strauss, A. L. (1967). The discovery of grounded theory: Strategies for qualitative research. Chicago, Illinois: Aldine Transaction.

Gleissman, S. (2013a). Agroecology: Growing the roots of resistance. Agroecology and Sustainable Food Systems, 37(1), 19-31. http://dx.doi.org/10.1080/10440046. 2012.736927

Gliessman, S. (2013b). Agroecology and going beyond organic. Agroecology and Sustainable Food Systems, 37(2), 147-148. http://dx.doi.org/10.1080/ 10440046.2012 .737448

Graham, R., \& Bertels, S. (2008). Achieving sustainable value: Sustainability portfolio assessment. Greener Management International, 54, 57-67.

Gupta, J., \& Sanchez, N. (2012). Global green governance: Embedding the green economy in a global green and equitable rule of law polity. Review of European Community and International Environmental Law, 21(1), 12-22. http://dx.doi.org/10.1111/ j.1467-9388.2012.00739.x
Guthman, J. (2004). The trouble with 'organic lite' in California: A rejoinder to the 'conventionalization' debate. Sociologia Ruralis, 44(3), 301-316. http://dx.doi.org/10.1111/j.14679523.2004.00277.x

Hammersley, M. (2011). On Becker's studies of marijuana use as an example of analytic induction. Philosophy of the Social Sciences, 41(4), 535-566. http://dx.doi.org/10.1177/0048393110367796

Hamilton, S. (2014). Agribusiness, the family farm, and the politics of technological determinism in the Post-World War II United States. Technology and Culture, 55(3), 560-590. http://dx.doi.org/10.1353/tech.2014.0067

Hecht, S. B. (2007). Factories, forests, fields and family: Gender and neoliberalism in extractive reserves. Journal of Agrarian Change, 7(3), 316-347. http://dx.doi.org/10.1111/j.14710366.2007.00148.x

Hernandez, D. C., \& Pressler, E. (2013). Maternal union transitions and household food insecurity: Differences by race and ethnicity. Journal of Family Issues, 34(3), 373-393. http://dx.doi.org/10.1177/0192513X12449134

Hitzhusen, F. J. (1992). The economics of sustainable agriculture: Adding a downstream perspective. Journal of Sustainable Agriculture, 2(2), 75-89. http://dx.doi.org/10.1300/J064v02n02_07

Hoag, D. L., \& Skold, M. D. (1996). The relationship between conservation and sustainability. Journal of Soil and Water Conservation, 51(4), 292-295. Retrieved from http:/ /www.jswconline.org/content/51/4/ 292.extract

Hulme, M. F., Vickery, J. A., Green, R. E., Phalan, B., Chamberlain, D. E., Pomeroy, D. E.,...Atkinson, P. W. (2013). Conserving the birds of Uganda's banana-coffee arc: Land sparing and land sharing compared. PLoS ONE, 8(2), 1-13. http://dx.doi.org/10.1371/journal.pone.0054597

Hutchins, M. J., \& Sutherland, J. W. (2008). An exploration of measures of social sustainability and their application to supply chain decisions. Journal of Cleaner Production, 16(15), 1688-1698. http://dx.doi.org/10.1016/j.jclepro.2008.06.001

Illge, L., \& Schwarze, R. (2009). A matter of opinionHow ecological and neoclassical environmental economists think about sustainability and economics. Ecological Economics, 68(3), 594-604. http://dx.doi.org/10.1016/j.ecolecon.2008.08.010 
Ingram, M. (2007). Biology and beyond: The science of "back to nature" farming in the United States. Annals of the Association of American Geographers, 97(2), 298-312. http://dx.doi.org/10.1111/j.14678306.2007.00537.x

Irvine, R. (2013). Food ethics: Issues of consumption and production: Self-restraint and voluntaristic measures are not enough. Journal of Bioethical Inquiry, 10(2), 145-148. http://dx.doi.org/10.1007/s11673013-9446-7

Jackson, W. (1971). Man and the environment. Dubuque, Iowa: William C. Brown Company.

Jacobsen, S.-E., Sorensen, M., Pedersen, S. M., \& Weiner, J. (2013). Feeding the world: Genetically modified crops versus agricultural biodiversity. Agronomy for Sustainable Development, 33(4), 651-662. http://dx.doi.org/10.1007/s13593-013-0138-9

Jaffee, D., \& Howard, P. H. (2010). Corporate cooptation of organic and fair trade standards. Agriculture and Human Values, 27(4), 387-399. http://dx.doi.org/10.1007/s10460-009-9231-8

Johanisova, N., Crabtree, T., \& Franková, E. (2013). Social enterprises and non-market capitals: A path to degrowth? Journal of Cleaner Production, 38, 7-16. http://dx.doi.org/10.1016/j.jclepro.2012.01.004

Johnston, J. (2008). The citizen-consumer hybrid: Ideological tensions and the case of Whole Foods Market. Theory and Society, 37(3), 229-270. http://dx.doi.org/10.1007/s11186-007-9058-5

Jones, C., \& Lyons, C. (2004). Case study: Design? Method? Or comprehensive strategy? Nurse Researcher, 11(3), 70-76. http://dx.doi.org/ $\underline{10.7748 / \mathrm{nr} 2004.04 .11 .3 .70 . \mathrm{c} 6206}$

Jordan, N. R., \& Davis, A. S. (2015). Middle-way strategies for sustainable intensification of agriculture. BioScience, 65(5), 513-519. http://dx.doi.org/10.1093/biosci/biv033

Kallis, G. (2011). In defence of degrowth. Ecological Economics, 70(5), 873-880. http://dx.doi.org/10.1016/j.ecolecon.2010.12.007

Kallis, G., Kerschner, C., \& Martinez-Alier, J. (2012). The economics of degrowth. Ecological Economics, 84, 172-180. http://dx.doi.org/10.1016/j.ecolecon.2012.08.017

Kastner, R., Rivas, M. J. I., Koch, W., \& Nonhebel, S. (2012). Global changes in diets and the consequences for land requirements for food.
Proceedings of the National Academy of Sciences in the United States of America, 109(18), 6868-6872. http://dx.doi.org/10.1073/pnas.1117054109

Kershen, D. L. (2013). The contested vision for agriculture's future: Sustainable intensive agriculture and agroecology. Creighton Law Review, 46(4), 591618. Retrieved from http://ssrn.com/abstract $=2353435$

Khan, M. H. (2011). Integrated livestock-fish production models for livelihood security in northeastern India. International Journal of Bio-Resources \& Stress Management, 2(3), 387-391.

Kirkegaard, J. A., Conyers, M. K., Hunt, J. R., Kirkby, C. A., Watt, M., \& Rebetzke, G. J. (2014). Sense and nonsense in conservation agriculture: Principles, pragmatism and productivity in Australian mixed farming systems. Agriculture, Ecosystems and Environment, 187, 133-145. http://dx.doi.org/10.1016/j.agee.2013.08.011

Kirner, L., \& Kratochvil, R. (2006). The role of farm size in the sustainability of dairy farming in Austria: An empirical approach based on farm accounting data. Journal of Sustainable Agriculture, 28(4), 105-124. http://dx.doi.org/10.1300/J064v28n04 09

Kirschenmann, F. (1991). Is sustainable agriculture the answer? Journal of Sustainable Agriculture, 1(2), 123130. http://dx.doi.org/10.1300/J064v01n02 08

Kirschenmann, F. (2004). A brief history of sustainable agriculture. The Networker, 9(2). Retrieved from http://www.sehn.org/Volume 9-2.html

Klinger, D., \& Naylor, R. (2012). Searching for solutions in aquaculture: Charting a sustainable course. Annual Review of Environment \& Resources, 37, 247276. http://dx.doi.org/10.1146/annurev-environ021111-161531

Krausmann, F., Erb, K.-H., Gingrich, S., Haberl, H., Bondeau, A., Gaube, V.,... Searchinger, T. D. (2013). Global human appropriation of net primary production doubled in the 20th century. Proceedings of the National Academy of Sciences in the United States of America, 110(25), 10324-10329. http://dx.doi.org/10.1073/pnas.1211349110

Kremen, C., Iles, A., \& Bacon, C. (2012). Diversified farming systems: An agroecological, systems-based alternative to modern industrial agriculture. Ecology and Society, 17(4), 288-306. http://dx.doi.org/10.5751/ES-05103-170444 
Kremen, C., \& Miles, A. (2012). Ecosystem services in biologically diversified versus conventional farming systems: Benefits, externalities and trade-offs. Ecology and Society, 17(4), 40. http://dx.doi.org/10.5751/ES-05035-170440

Kull, C. A., Carrière, S. M., Moreau, S., Ramiarantsoa, H. R., Blanc-Pamard, C., \& Tassin, J. (2013). Melting pots of biodiversity: Tropical smallholder farm landscapes as guarantors of sustainability. Environment, 55(2), 6-16. http://dx.doi.org/10.1080/00139157.2013.765307

Lal, R. (2015). Sequestering carbon and increasing productivity by conservation agriculture. Journal of Soil and Water Conservation, 70(3), 55A-62A. http://dx.doi.org/10.2489/jswc.70.3.55A

Laurance, W. F., Sayer, J., \& Cassman, K. G. (2014). Agricultural expansion and its impacts on tropical nature. Trends in Ecology and Evolution, 29(2), 107116. http://dx.doi.org/10.1016/j.tree.2013.12.001

Lengnick, L. (2015). Resilient agriculture: Cultivating food systems for a changing climate. Gabriola Island, British Columbia, Canada: New Society Publishers.

Leopold, A. (1949). A Sand County almanac: And sketches here and there. Oxford, United Kingdom: Oxford University Press.

Leopold, A. (1966). A Sand County almanac with essays on conservation from Round River. New York: Ballantine.

Levidow, L., Pimbert, M., \& Vanloqueren, G. (2014). Agroecological research: Conforming-or transforming the dominant agro-food regime? Agroecology and Sustainable Food Systems, 38(10), 1127-1155. http://dx.doi.org/10.1080/21683565.2014.951459

Lighthall, D. R. (1996). Sustainable agriculture in the Corn Belt: Production-side progress and demandside constraints. American Journal of Alternative Agriculture, 11(4), 168-174. http://dx.doi.org/10.1017/S0889189300007013

Lloyd-Jones, G. (2003). Design and control issues in qualitative case study research. International Journal of Qualitative Methods, 2(2), 1-20. http:/ /www.ualberta. $\mathrm{ca} /$ iiqm/backissues/2 2/pdf/lloydjones.pdf

Lockie, S., \& Halpin, D. (2005). The 'conventionalisation' thesis reconsidered: Structural and ideological transformation of Australian organic agriculture. Sociologia Ruralis, 45(4), 284-307. http://dx.doi.org/ 10.1111/j.1467-9523.2005.00306.x

Lockie, S., Lyons, K., Lawrence, G., \& Mummery, K. (2002). Eating 'green': Motivations behind organic food consumption in Australia. Sociologia Ruralis, 42(1), 23-40. http://dx.doi.org/10.1111/1467$\underline{9523.00200}$

Lovett, J. V. (1990). Sustainable agriculture: A global overview. Social Alternatives, 9(3), 4-7.

Lu, Y.-C., Watkins, B., \& Teasdale, J. (1999). Economic analysis of sustainable agricultural cropping systems for Mid-Atlantic states. Journal of Sustainable Agriculture, 15(2-3), 77-93.

http://dx.doi.org/10.1300/J064v15n02 09

Lyson, T. A., \& Welsh, R. (1993). The production function, crop diversity, and the debate between conventional and sustainable agriculture. Rural Sociology, 58(3), 424-439. http://dx.doi.org/ 10.1111/j.1549-0831.1993.tb00503.x

Mackey, M., \& Montgomery, J. (2004). Plant biotechnology can enhance food security and nutrition in the developing world. Nutrition Today, 39(2), 52-58. http://dx.doi.org/10.1097/00017285200403000-00003

Madden, P. (1987). Can sustainable agriculture be profitable? Environment, 29(4), 18-34.

http://dx.doi.org/10.1080/00139157.1987.9928880

Mandell, B. (2009). Cultivating race: How the science and technology of agriculture preserves race in the global economy. Albany Law Review, 72(4), 939-951.

Marra, M. C., \& Kaval, P. (2000). The relative profitability of sustainable grain cropping systems: A meta-analytic comparison. Journal of Sustainable Agriculture, 16(4), 19-33. http://dx.doi.org/10.1300/J064v16n0404

Martínez-Alier, J., Pascual, U., Vivien, F.-D., \& Zaccai, E. (2010). Sustainable de-growth: Mapping the context, criticisms and future prospects of an emergent paradigm. Ecological Economics, 69(9), 1741-1747. http://dx.doi.org/10.1016/j.ecolecon.2010.04.017

Martins, N. O. (2013). The place of the capability approach within sustainability economics. Ecological Economics, 95, 226-230. http://dx.doi.org/10.1016/j.ecolecon.2013.07.004

Marzano, R. J. (2011). The perils and promises of discovery learning. Educational Leadership, 69(1), 8687. Retrieved from http://www.ascd.org/publica tions/educational-leadership/sept11/vol69/ num01/The-Perils-and-Promises-of-DiscoveryLearning.aspx 
Masters, M. A., Krogstrand, K. L. S., Eskridge, K. M., \& Albrecht, J. A. (2014). Race/ethnicity and income in relation to the home food environment in US youth aged 6 to 19 years. Journal of the Academy of Nutrition and Dietetics, 114(10), 1533-1543. http://dx.doi.org/10.1016/i.jand.2014.04.023

Maurino, V. G., \& Weber, A. P. M. (2013). Engineering photosynthesis in plants and synthetic microorganisms. Journal of Experimental Botany, 64(3), 743751. http://dx.doi.org/10.1093/jxb/ers263

McGloughlin, M. N. (2010). Modifying agricultural crops for improved nutrition. New Biotechnology, 27(5), 494-504.

http://dx.doi.org/10.1016/j.nbt.2010.07.013

McMahon, S., \& Fleury, J. (2012). Wellness in older adults: A concept analysis. Nursing Forum, 47(1), 39-51. http://dx.doi.org/10.1111/j.17446198.2011.00254.x

Meléndez-Ortiz, R. (2011). Governance of international trade for the green economy. Review of Policy Research, 28(5), 479-486. http://dx.doi.org/ 10.1111/j.1541-1338.2011.00514.x

Miller, Z. J., \& Menalled, F. D. (2015). Impact of species identity and phylogenetic relatedness on biologically-mediated plant-soil feedbacks in a low and a high intensity agroecosystem. Plant and Soil, 389(1), 171-183. http://dx.doi.org/10.1007/s11104-014-2336-x

Minkoff-Zern, L.-A. (2014). Knowing “good food”: Immigrant knowledge and the racial politics of farmworker food insecurity. Antipode, 46(5), 1190-1204. http://dx.doi.org/10.1111/j.14678330.2012.01016.x

Mundler, P., \& Rumpus, L. (2012). The energy efficiency of local food systems: A comparison between different modes of distribution. Food Policy, 37(6), 609-615.

http://dx.doi.org/10.1016/j.foodpol.2012.07.006

Murdock, S. H., Leistritz, F. L., \& Hamm, R. A. (1988). Impacts of the farm financial crisis of the 1980s on resources and poverty in agriculturally dependent counties in the United States. Review of Policy Research, 7(4), 810-827. http://dx.doi.org/10.1111/ j.1541-1338.1988.tb00898.x

Nelson, R., \& Coe, R. (2014). Transforming research and development practice to support agroecological intensification of smallholder farming. Journal of International Affairs, 67(2), 107-127. Retrieved from http://jia.sipa.columbia.edu/transformingresearch-and-development-practice-to-supportagroecological-intensification-of-smallholderfarming/

Norman, D., Bloomquist, L., Janke, R., Freyenberger, S., Jost, J., Schurle, B., \& Kok, H. (2000). The meaning of sustainable agriculture: Reflections of some Kansas practitioners. American Journal of Alternative Agriculture, 15(3), 129-136.

http://dx.doi.org/10.1017/S088918930000864X

Nori, J., Lescano, J. N., Illoldi-Rangel, P., Frutos, N., Cabrera, M. R., \& Leynaud, G. C. (2013). The conflict between agricultural expansion and priority conservation areas: Making the right decisions before it is too late. Biological Conservation, 159, 507-513. http://dx.doi.org/10.1016/j.biocon.2012.11.020

Northcutt, N., \& McCoy, D. (2004). Comparisons, interpretations, and theories: Some examples. In N. Northcutt \& D. McCoy, Interactive Qualitative Analysis: A Systems Method for Qualitative Research (pp. 394-424). Thousand Oaks, California: SAGE.

Odegard, I. Y. R., \& van der Voet, E. (2014). The future of food-Scenarios and the effect on natural resource use in agriculture in 2050. Ecological Economics, 97, 51-59. http://dx.doi.org/10.1016/j.ecolecon.2013.10.005

Oelofse, M., Høgh-Jensen, H., Abreu, L. S., Almeida, G. F., El-Araby, A., Hui, Q. Y.,...de Neergaard, A. (2011). Organic farm conventionalisation and farmer practices in China, Brazil and Egypt. Agronomy for Sustainable Development, 31(4), 689-698. http://dx.doi.org/10.1007/s13593-011-0043-z

Ogello, E. O., Mlingi, F. T., Nyonje, B. M., Charo-Karis, H., \& Munguti, J. M. (2013). Can integrated livestock-fish culture be a solution to East African's food insecurity? A review. African Journal of Food, Agriculture, Nutrition \& Development, 13(4), 80588076. Retrieved from http://www.ajol.info/ index.php/ajfand/article/view/94601

Omer, A., Pascual, U., \& Russell, N. (2010). A theoretical model of agrobiodiversity as a supporting service for sustainable agricultural intensification. Ecological Economics, 69(10), 1926-1933. http://dx.doi.org/10.1016/j.ecolecon.2010.04.025

Painter, K. (1991). Does sustainable farming pay: A case study. Journal of Sustainable Agriculture, 1(3), 37-48. http://dx.doi.org/10.1300/j064v01n03 04 
Pearson, C. J. (2007). Regenerative, semiclosed systems: A priority for twenty-first-century agriculture.

Bioscience, 57(5), 409-418.

http://dx.doi.org/10.1641/B570506

Pechrová, M. (2014). Determinants of the farmers' conversion to organic and biodynamic agriculture. Agris On-Line Papers in Economics and Informatics, 6(4), 113-120. Retrieved from http://purl.umn.edu/196581

Perfecto, I., Vandermeer, J., \& Philpott, S. M. (2014). Complex ecological interactions in the coffee agroecosystem. Annual Review of Ecology, Evolution, and Systematics, 45, 137-158. http://dx.doi.org/ 10.1146/annurev-ecolsys-120213-091923

Pilgeram, R. (2011). "The only thing that isn't sustainable...is the farmer": Social sustainability and the politics of class among Pacific Northwest farmers engaged in sustainable farming. Rural Sociology, 76(3), 375-393. http://dx.doi.org/ 10.1111/j.1549-0831.2011.00051.x

Pilkington, L. J., Messelink, G., van Lenteren, J. C., \& Le Mottee, K. (2010). "Protected biological control"Biological pest management in the greenhouse industry. Biological Control, 52(3), 216-220. http://dx.doi.org/10.1016/j.biocontrol.2009.05.022

Pliego, C., Ramos, C., de Vicente, A., \& Cazorla, F. M. (2011). Screening for candidate bacterial biocontrol agents against soilborne fungal plant pathogens. Plant and Soil, 340(1), 505-520. http://dx.doi.org/10.1007/s11104-010-0615-8

Prasad, R. (2013). Population growth, food shortages and ways to alleviate hunger. Current Science, 105(1), 32-36. Retrieved from http://www.currentsci ence.ac.in/Volumes/105/01/0032.pdf

Pratt, J. (2009). Incorporation and resistance: Analytical issues in the conventionalization debate and alternative food chains. Journal of Agrarian Change, 9(2), 155-174. http://dx.doi.org/10.1111/j.14710366.2009.00190.x

Pretty, J. (2009). Can ecological agriculture feed nine billion people? Monthly Review, 61(6), 46-58. http://dx.doi.org/10.14452/MR-061-06-2009-10 5

Pretty, J., \& Bharucha, Z. P. (2014). Sustainable intensification in agricultural systems. Annals of Botany, 114(8), 1571-1596. http://dx.doi.org/10.1093/aob/mcu205

Radley, A., \& Chamberlain, K. (2012). The study of the case: Conceptualising case study research. Journal of Community and Applied Social Psychology, 22(5), 390-
399. http://dx.doi.org/10.1002/casp.1106

Reganold, J. P., Papendick, R. I., \& Parr, J. F. (1990). Sustainable agriculture. Scientific American, 262, 112120. http://dx.doi.org/10.1038/scientificamerican 0690-112

Reinhardt, N., \& Barlett, P. (1989). The persistence of family farms in United States agriculture. Sociologia Ruralis, 29(3-4), 203-225. http:/ / dx.doi.org/ 10.1111/j.1467-9523.1989.tb00367.x

Rigby, D., \& Cáceres, D. (2001). Organic farming and the sustainability of agricultural systems. Agricultural Systems, 68(1), 21-40. http://dx.doi.org/10.1016/ $\underline{\text { S0308-521X }(00) 00060-3}$

Robinson, J. G. (2011). Ethical pluralism, pragmatism, and sustainability in conservation practice. Biological Conservation, 144(3), 958-965. http://dx.doi.org/10.1016/j.biocon.2010.04.017

Rochecouste, J.-F., Dargusch, P., Cameron, D., \& Smith, C. (2015). An analysis of the socio-economic factors influencing the adoption of conservation agriculture as a climate change mitigation activity in Australian dryland grain production. Agricultural Systems, 135, 20-30. http://dx.doi.org/10.1016/j.agsy.2014.12.002

Rosegrant, M. W., \& Livernash, R. (1996). Growing more food, doing less damage. Environment, 38(7), 6-32.

http://dx.doi.org/10.1080/00139157.1996.9930980

Rosset, P. M., \& Altieri, M. A. (1997). Agroecology versus input substitution: A fundamental contradiction of sustainable agriculture. Society and Natural Resources, 10(3), 283-295. http://dx.doi.org/10.1080/08941929709381027

Rovira-Más, F., \& Sáiz-Rubio, V. (2013). Crop biometric maps: The key to prediction. Sensors, 13(9), 1269812743. http://dx.doi.org/10.3390/s130912698

Rubaie, T. A. (2002). The rehabilitation of the casestudy method. European Journal of Psychotherapy, Counselling and Health, 5(1), 31-47. http://dx.doi.org/10.1080/13642530210159198

Ruttan, V. W. (1996). The transition to agricultural sustainability. Proceedings of the National Academy of Sciences of the United States of America, 96(11), 59605967. http://dx.doi.org/10.1073/pnas.96.11.5960

Ruttan, V. W. (2000). The continuing challenge of food production: Food in the 21st century: From science to sustainable agriculture. Environment, 42(10), 2530. http://dx.doi.org/10.1080/00139150009605772 
Saab, N., van Joolingen, W. R., \& van Hout-Wolters, B. H. A. M. (2005). Communication in collaborative discovery learning. British Journal of Educational Psychology, 75(4), 603-621. http://dx.doi.org/10.1348/000709905X42905

Sabto, M. (2014). Food security and the role of 'sustainable intensification.' Ecos. Retrieved from http://www.ecosmagazine.com/?paper=EC14167

Saldaña, J. (2012). The coding manual for qualitative researchers. Los Angeles: SAGE.

Saltiel, J., Bauder, J. W., \& Palakovich, S. (1994). Adoption of sustainable agriculture practices: Diffusion, farm structure, and profitability. Rural Sociology, 59(2), 333-349. http://dx.doi.org/ 10.1111/j.1549-0831.1994.tb00536.x

Sekulova, F., Kallis, G., Rodríguez-Labajos, B., \& Schneider, F. (2013). Degrowth: From theory to practice. Journal of Cleaner Production, 38, 1-6. http://dx.doi.org/10.1016/j.jclepro.2012.06.022

Seufert, V., Ramankutty, N., \& Foley, J. A. (2012). Comparing the yields of organic and conventional agriculture. Nature, 485(7397), 229-232. http://dx.doi.org/10.1038/nature11069

Seyfang, G., \& Longhurst, N. (2013). Growing green money? Mapping community currencies for sustainable development. Ecological Economics, 86, 65-77.

http://dx.doi.org/10.1016/j.ecolecon.2012.11.003

Smaje, C. (2014). Kings and commoners: Agroecology meets consumer culture. Journal of Consumer Culture, 14(3), 365-383. http://dx.doi.org/10.1177/1469540513488406

Smerdon, J.E., Cook, B.I., Cook, E.R., \& Seager, R. (2015). Bridging past and future climate across paleoclimatic reconstructions, observations and models: A hydroclimate case study. Journal of Climate, 28(2), 3212-3231. http://dx.doi.org/10.1175/JCLI-D-14-00417.1

Sonnino, R. (2013). Local foodscapes: Place and power in the agri-food system. Acta Agriculturae Scandinavica, Section B - Soil and Plant Science, 63(Supp. 1), 2-7. http://dx.doi.org/10.1080/09064710.2013.800130

Sorman, A. H., \& Giampietro, M. (2013). The energetic metabolism of societies and the degrowth paradigm: Analyzing biophysical constraints and realities. Journal of Cleaner Production, 38, 80-93. http://dx.doi.org/10.1016/j.jclepro.2011.11.059
Tavernier, E. M., \& Tolomeo, V. (2004). Farm typology and sustainable agriculture: Does size matter? Journal of Sustainable Agriculture, 24(2), 33-46. http://dx.doi.org/10.1300/J064v24n02 05

Teixeira, R. F. M., Proença, V., Crespo, D., Valada, T., \& Domingos, T. (2015). A conceptual framework for the analysis of engineered biodiverse pastures. Ecological Engineering, 77, 85-97. http://dx.doi.org/10.1016/j.ecoleng.2015.01.002

Tiley, F., \& Young, W. (2009). Sustainability entrepreneurs: Could they be the true wealth generators of the future? Greener Management International, 55, 79-92.

Tilman, D., Balzer, C., Hill, J., \& Befort, B. L. (2011). Global food demand and the sustainable intensification of agriculture. Proceedings of the National Academy of Sciences of the United States of America, 108(50), 20260-20264. http://dx.doi.org/10.1073/pnas.1116437108

U.S. Department of Agriculture, Sustainable Agriculture Research \& Education Program. (2012). Historical timeline. Retrieved July 14, 2015, from http://www.sare.org/About-SARE/HistoricalTimeline

Urquhart, C., \& Fernández, W. (2013). Using grounded theory method in information systems: The researcher as blank slate and other myths. Journal of Information Technology, 28, 224-236. http://dx.doi.org/10.1057/jit.2012.34

van Ittersum, M. K., Cassman, K. G., Grassini, P., Wolf, J., Tittonell, P., \& Hochman, Z. (2013). Yield gap analysis with local to global relevance-A review. Field Crops Research, 143, 4-17. http://dx.doi.org/10.1016/j.fcr.2012.09.009

Varul, M. Z. (2008). Consuming the campesino: Fair trade marketing between recognition and romantic commodification. Cultural Studies, 22(5), 654-679. http://dx.doi.org/10.1080/09502380802245910

Walsh, R., \& Lyson, T. A. (1997). Farm structure, market structure and agricultural sustainability goals: The case of New York dairying. American Journal of Alternative Agriculture, 12(1), 14-18. http://dx.doi.org/10.1017/S0889189300007128

Wang, C., \& Pang, C. (2013). The design of protected agriculture monitoring systems based on GIS-A case study of Qiqihar. International Journal of $u$ - and eService, Science \& Technology, 6(5), 25-38. http://dx.doi.org/10.14257/ijunesst.2013.6.5.03 
Wezel, A., Casagrande, M., Celette, F., Vian, J.-F., Ferrer, A., \& Peigné, J. (2014). Agroecological practices for sustainable agriculture: A review. Agronomy for Sustainable Development, 34(1), 1-20. http://dx.doi.org/10.1007/s13593-013-0180-7

Wield, D., Chataway, J., \& Bolo, M. (2010). Issues in the political economy of agricultural biotechnology.

Journal of Agrarian Change, 10(3), 342-366. http://dx.doi.org/10.1111/j.1471-0366.2010. 00274.x

Wilkinson, J. (2009). The globalization of agribusiness and developing world food systems. Monthly Review, 61(4), 38-50. http://dx.doi.org/10.14452/MR-06104-2009-08_4

Wilson, B. R., \& Curnow, J. (2013). Solidarity: Student activism, affective labor, and the fair trade campaign in the United States. Antipode, 45(3), 565583. http://dx.doi.org/10.1111/j.1467-8330. 2012.01051.x

Woodhouse, P. (2010). Beyond industrial agriculture? Some questions about farm size, productivity and sustainability. Journal of Agrarian Change, 10(3), 437453. http://dx.doi.org/10.1111/j.1471-0366. 2010.00278.x

Woods, M. (2014). Family farming in the global countryside. Anthropological Notebooks, 20(3), 31-48. Retrieved from http://www.drustvo-antropologov. si/AN/PDF/2014_3/Anthropological_Notebooks XX 3 Woods.pdf
Woods, T., Velandia, M., Holcomb, R., Dunning, R., \& Benefeldt, E. (2013). Local food systems markets and supply chains. Choices, 28(4), 1-4. Retrieved from http://www.choicesmagazine.org/choicesmagazine/theme-articles/developing-local-foodsystems-in-the-south/local-food-systems-marketsand-supply-chains

Wright, A. L., \& Snyder, G. H. (2009). Soil subsidence in the Everglades Agricultural Area (Publication No. SL 311). Retrieved June 5, 2014, from http://edis.ifas.ufl.edu/ss523

Yang, N.-W., Zang, L.-S., Wang, S., Guo, J.-Y., Xu, H.X., Zhang, F., \& Wan, F.-H. (2014). Biological pest management by predators and parasitoids in the greenhouse vegetables in China. Biological Control, 68, 92-102. http://dx.doi.org/10.1016/j.biocontrol.2013.06.012

Yin, R. K. (2009) Case Study Research: Design and Methods (4th Ed.). Thousand Oaks, California: SAGE.

Zander, K., \& Hamm, U. (2010). Consumer preferences for additional ethical attributes of organic food. Food Quality and Preference, 21(5), 495-503. http://dx.doi.org/10.1016/j.foodqual.2010.01.006

Zimmermann, K., Aurich, P., Graziano, P. R., \& Fuertes, V. (2014). Local worlds of marketizationEmployment policies in Germany, Italy and the UK compared. Social Policy \& Administration, 48(2), 127148. http://dx.doi.org/10.1111/spol.12053 


\begin{tabular}{|c|c|c|c|c|c|c|c|}
\hline & Dimensions & Case 1 & Case 2 & Case 3 & Case 4 & Case 5 & Case 6 \\
\hline Change & $\begin{array}{l}\text { 2. Consumer } \\
\text { Interest and } \\
\text { Demand }\end{array}$ & $\begin{array}{l}\text { - Almost half the } \\
\text { farm dedicated to } \\
\text { organics; sees this } \\
\text { as a growing } \\
\text { market. }\end{array}$ & $\begin{array}{l}\text { Meeting high-end } \\
\text { demand with } \\
\text { premium products. }\end{array}$ & $\begin{array}{l}\text { - Certified organic. } \\
\text { - Certified carbon } \\
\text { free. } \\
\text { - Earth friendly. } \\
\text { - Certified by Vegan } \\
\text { Action. } \\
\text { - Grown in USA. } \\
\text { - Recyclable } \\
\text { containers. }\end{array}$ & $\begin{array}{l}\text { - Anticipates in- } \\
\text { creasing interest in } \\
\text { poultry. }\end{array}$ & $\begin{array}{l}\text { - Started farming } \\
\text { because } \\
\text { recognized } \\
\text { demand in local } \\
\text { community. }\end{array}$ & \\
\hline
\end{tabular}




\begin{tabular}{|c|c|c|c|c|c|c|c|}
\hline & Dimensions & Case 1 & Case 2 & Case 3 & Case 4 & Case 5 & Case 6 \\
\hline & $\begin{array}{l}\text { 3. Environ- } \\
\text { mental }\end{array}$ & $\begin{array}{l}\text { - Started having } \\
\text { buyers pay up front } \\
\text { to alleviate cost of } \\
\text { losing crops to } \\
\text { weather. }\end{array}$ & & $\begin{array}{l}\text { - Implementing soil } \\
\text { conservation } \\
\text { practices. } \\
\text { - Traded land with } \\
\text { Everglades Forever } \\
\text { to create a buffer. } \\
\text { - Measure amount } \\
\text { of phosphorus } \\
\text { going in and out. } \\
\text { - Extract their own } \\
\text { energy. }\end{array}$ & & & $\begin{array}{l}\text { - Cleaning water } \\
\text { that leaves the } \\
\text { farm. }\end{array}$ \\
\hline \multirow{3}{*}{$\begin{array}{l}\text { Limitations } \\
\text { and } \\
\text { Resources }\end{array}$} & 1. Human & $\begin{array}{l}\text { Has a loyal work- } \\
\text { force and ensures } \\
\text { they are happy. }\end{array}$ & $\begin{array}{l}\text { - Loyal, long-term } \\
\text { employees who } \\
\text { intimately under- } \\
\text { stood the busi- } \\
\text { ness. } \\
\text { - Local community } \\
\text { and other busi- } \\
\text { nesses. }\end{array}$ & $\begin{array}{l}\text { - Turned a labor } \\
\text { problem into an } \\
\text { advantage: full- } \\
\text { time skilled labor } \\
\text { force and better } \\
\text { reputation. }\end{array}$ & $\begin{array}{l}\text { - Limitation: single } \\
\text { owner } \rightarrow \text { hired } \\
\text { friend to help. }\end{array}$ & $\begin{array}{l}\text { - Volunteer labor } \\
\text { force (CSA mem- } \\
\text { bers subsidizing } \\
\text { their shares). }\end{array}$ & $\begin{array}{l}\text { - Limitation: not } \\
\text { good at finishing } \\
\text { cows } \rightarrow \text { focuses } \\
\text { on breeding and } \\
\text { ships elsewhere } \\
\text { for finishing }\end{array}$ \\
\hline & $\begin{array}{l}\text { 2. Environ- } \\
\text { mental }\end{array}$ & & $\begin{array}{l}\text { - Small amount of } \\
\text { land } \rightarrow \text { maximized } \\
\text { output in small } \\
\text { space. }\end{array}$ & $\begin{array}{l}\text { - Everglades. } \\
\text { - Use waste on farm } \\
\text { to generate profit. }\end{array}$ & - Limited space. & & $\begin{array}{l}\text { - Competition for } \\
\text { water from } \\
\text { population. }\end{array}$ \\
\hline & 3. Fiscal & $\begin{array}{l}\text { - Only sells to } \\
\text { reliable buyers. }\end{array}$ & - Uses credit. & $\begin{array}{l}\text { - Counties pay them } \\
\text { to take lawn waste } \\
\text { - Sell energy to local } \\
\text { communities. }\end{array}$ & $\begin{array}{l}\text { - Operates on tight } \\
\text { budget } \rightarrow \\
\text { purchases used } \\
\text { equipment to } \\
\text { leverage money. }\end{array}$ & $\begin{array}{l}\text { - Not relying on the } \\
\text { farm for primary } \\
\text { source of income. } \\
\text { - Permanent farm } \\
\text { stand on property. }\end{array}$ & $\begin{array}{l}\text { - Support from } \\
\text { larger network. }\end{array}$ \\
\hline $\begin{array}{l}\text { Relation- } \\
\text { ships }\end{array}$ & $\begin{array}{l}\text { 1. Service to the } \\
\text { Community }\end{array}$ & & $\begin{array}{l}\text { - Open the farm to } \\
\text { guests for farm- } \\
\text { to-fork dinners; } \\
\text { proceeds go to } \\
\text { local charities. } \\
\text { - Donates unsold } \\
\text { or short-dated } \\
\text { products to } \\
\text { community } \\
\text { groups and food } \\
\text { banks. }\end{array}$ & & $\begin{array}{l}\text { - Works with } \\
\text { Extension to offer } \\
\text { education } \\
\text { programs. } \\
\text { - Active in policy to } \\
\text { improve small } \\
\text { farm poultry } \\
\text { farmers. }\end{array}$ & $\begin{array}{l}\text { - Open access for } \\
\text { community } \\
\text { members. }\end{array}$ & $\begin{array}{l}\text { - Donates food to } \\
\text { community. } \\
\text { - Open facility to } \\
\text { community groups } \\
\text { and camps to use. }\end{array}$ \\
\hline
\end{tabular}




\begin{tabular}{|c|c|c|c|c|c|c|c|}
\hline & Dimensions & Case 1 & Case 2 & Case 3 & Case 4 & Case 5 & Case 6 \\
\hline & $\begin{array}{l}\text { 2. Being a Good } \\
\text { Neighbor }\end{array}$ & & $\begin{array}{l}\text { - Very tied into } \\
\text { community net- } \\
\text { works and takes } \\
\text { care of the com- } \\
\text { munity in any way } \\
\text { she can. } \\
\end{array}$ & & $\begin{array}{l}\text { - Traded equipment } \\
\text { and supplies with } \\
\text { other community } \\
\text { members. }\end{array}$ & & $\begin{array}{l}\text { Used tractors to } \\
\text { clear roads after } \\
\text { hurricane. }\end{array}$ \\
\hline \multirow{3}{*}{$\begin{array}{l}\text { Human } \\
\text { Resources }\end{array}$} & $\begin{array}{l}\text { 1. Empower- } \\
\text { ment }\end{array}$ & & $\begin{array}{l}\text { - Openly valued and } \\
\text { respected } \\
\text { employees. } \\
\text { - Encouraged } \\
\text { employees to } \\
\text { experiment and do } \\
\text { things that interest } \\
\text { them. }\end{array}$ & $\begin{array}{l}\text { - Workers are part } \\
\text { of a union. }\end{array}$ & & & \\
\hline & $\begin{array}{l}\text { 2. Incentive } \\
\text { Programs }\end{array}$ & & & $\begin{array}{l}\text { - Advancement } \\
\text { opportunities. }\end{array}$ & & & $\begin{array}{l}\text { - Professional } \\
\text { development. } \\
\text { - Advancement } \\
\text { opportunities. }\end{array}$ \\
\hline & $\begin{array}{l}\text { 3. Life } \\
\text { Satisfaction }\end{array}$ & $\begin{array}{l}\text { - Livable wages and } \\
\text { benefits. } \\
\text { - Transportation to } \\
\text { and from farm. } \\
\text { - Atypical model: } \\
\text { direct-hires his } \\
\text { own field labor. } \\
\text { - Restrooms in field. }\end{array}$ & $\begin{array}{l}\text { - Ended volunteer } \\
\text { program because } \\
\text { employees weren't } \\
\text { happy supervising } \\
\text { volunteers and } \\
\text { wanted to spend } \\
\text { their time on the } \\
\text { farm doing things } \\
\text { they enjoy. } \\
\text { - Livable wages and } \\
\text { benefits. } \\
\text { - Given food from } \\
\text { farm. }\end{array}$ & $\begin{array}{l}- \text { Livable wages and } \\
\text { benefits. }\end{array}$ & & - Livable wages. & $\begin{array}{l}\text { - Livable wages and } \\
\text { benefits with } \\
\text { retirement } \\
\text { accounts and } \\
\text { profit sharing. }\end{array}$ \\
\hline Quality & Quality & $\begin{array}{l}\text { - Proud of premium } \\
\text { price. } \\
\text { - Superior } \\
\text { eggplants. } \\
\text { - Beating out } \\
\text { competition } \\
\text { (Mexico) in terms } \\
\text { of product and } \\
\text { safety. } \\
\text { - Organic. }\end{array}$ & $\begin{array}{l}\text { - Proud of premium } \\
\text { price. } \\
\text { - Sells at high-end } \\
\text { restaurants. } \\
\text { - Sells unique } \\
\text { products: edible } \\
\text { flowers, } \\
\text { dehydrated } \\
\text { products. }\end{array}$ & $\begin{array}{l}\text { - Proud of premium } \\
\text { price. } \\
\text { - Offer a patented } \\
\text { product that no } \\
\text { one else is able to } \\
\text { replicate. } \\
\text { - Rice is unique. }\end{array}$ & $\begin{array}{l}\text { - Proud of premium } \\
\text { price. } \\
\text { - Sells at high-end } \\
\text { restaurants and } \\
\text { country clubs. }\end{array}$ & $\begin{array}{l}\text { - Proud of premium } \\
\text { price. }\end{array}$ & $\begin{array}{l}\text { - Strong breeding } \\
\text { program producing } \\
\text { more cattle than } \\
\text { many other Florida } \\
\text { ranches and with } \\
\text { better cuts of } \\
\text { meet. }\end{array}$ \\
\hline
\end{tabular}




\begin{tabular}{|c|c|c|c|c|c|c|c|}
\hline & Dimensions & Case 1 & Case 2 & Case 3 & Case 4 & Case 5 & Case 6 \\
\hline \multirow{3}{*}{$\begin{array}{l}\text { Manage- } \\
\text { ment }\end{array}$} & $\begin{array}{l}\text { 1. Distribution } \\
\text { of Responsi- } \\
\text { bility }\end{array}$ & $\begin{array}{l}\text { Limited distribu- } \\
\text { tion of responsi- } \\
\text { bility to family. }\end{array}$ & $\begin{array}{l}\text { - Individual employ- } \\
\text { ees managed } \\
\text { different units of } \\
\text { the farm. }\end{array}$ & $\begin{array}{l}\text { - Management } \\
\text { divided into units. }\end{array}$ & $\begin{array}{l}\text { - Individual employ- } \\
\text { ees managed } \\
\text { certain aspects of } \\
\text { the farm. }\end{array}$ & $\begin{array}{l}\text { - Volunteers and } \\
\text { paid employees } \\
\text { had separate } \\
\text { responsibilities. }\end{array}$ & $\begin{array}{l}\text { - Divided farm into } \\
\text { smaller units } \\
\text { managed by } \\
\text { independent } \\
\text { teams. }\end{array}$ \\
\hline & 2. Diversity & & $\begin{array}{l}\text { - Employees pursue } \\
\text { things on the farm } \\
\text { that they were } \\
\text { good at. }\end{array}$ & $\begin{array}{l}\text { - Hire the most } \\
\text { skilled people to } \\
\text { manage. } \\
\text { - Hire experts to } \\
\text { accomplish their } \\
\text { goals. }\end{array}$ & & & $\begin{array}{l}\text { - Subcontract for } \\
\text { things they aren't } \\
\text { good at. }\end{array}$ \\
\hline & 3. Integration & & & & & & $\begin{array}{l}\text { - Standard operat- } \\
\text { ing procedures for } \\
\text { the entire farm. } \\
\text { - Monthly manage- } \\
\text { ment meeting } \\
\text { evaluating general } \\
\text { procedures and } \\
\text { processes and } \\
\text { looked for ways to } \\
\text { share resources } \\
\text { across units. }\end{array}$ \\
\hline \multirow{2}{*}{$\begin{array}{l}\text { A Farm Is a } \\
\text { Business }\end{array}$} & $\begin{array}{l}\text { 1. Reinvest- } \\
\text { ment }\end{array}$ & $\begin{array}{l}\text { - Used capital to } \\
\text { stabilize the } \\
\text { business and be } \\
\text { less vulnerable to } \\
\text { brokers in the } \\
\text { future. }\end{array}$ & $\begin{array}{l}\text { - Reinvested profits } \\
\text { into business to } \\
\text { expand product } \\
\text { offerings. }\end{array}$ & $\begin{array}{l}\text { - Investing in } \\
\text { research to } \\
\text { improve practices } \\
\text { and products. }\end{array}$ & $\begin{array}{l}\text { - Purchased } \\
\text { incubator to get a } \\
\text { better hatch rate. } \\
\text { - Feeders. } \\
\text { - Shed. } \\
\text { - Chick house. }\end{array}$ & $\begin{array}{l}\text { - Built digesters/ } \\
\text { vermicomposting } \\
\text { - Hoop houses }\end{array}$ & \\
\hline & 2. Social Goals & & $\begin{array}{l}\text { - Donated to local } \\
\text { organizations. }\end{array}$ & $\begin{array}{l}\text { Provides support } \\
\text { to local organiza- } \\
\text { tions addressing } \\
\text { education, and } \\
\text { literacy. }\end{array}$ & & & \\
\hline
\end{tabular}




\begin{tabular}{|c|c|c|c|c|c|c|c|}
\hline & Dimensions & Case 1 & Case 2 & Case 3 & Case 4 & Case 5 & Case 6 \\
\hline & $\begin{array}{l}\text { 3. Environmen- } \\
\text { tal Goals }\end{array}$ & & & $\begin{array}{l}\text { - Provides support } \\
\text { to local organiza- } \\
\text { tions addressing } \\
\text { wildlife and } \\
\text { environment. }\end{array}$ & & & $\begin{array}{l}\text { - Preserve the land } \\
\text { forever. } \\
\text { - Using profits to } \\
\text { clean water as it } \\
\text { leaves the farm. } \\
\text { - Using profits to } \\
\text { maintain a wildlife } \\
\text { conservation area. }\end{array}$ \\
\hline \multirow[t]{2}{*}{ Planning } & $\begin{array}{l}\text { 1. Risk and } \\
\text { Investment }\end{array}$ & $\begin{array}{l}\text { - Alleviated risk by } \\
\text { only selling to } \\
\text { brokers with a } \\
\text { good track record, }\end{array}$ & $\begin{array}{l}\text { - Took out a line of } \\
\text { credit to purchase } \\
\text { new equipment } \\
\text { that would allow } \\
\text { her to diversify the } \\
\text { operation. }\end{array}$ & & & & - Don't take on risk. \\
\hline & 2. Visioning & - 10 years. & & $\begin{array}{l}\text { - Plan for long term } \\
\text { sustainability of } \\
\text { the business and } \\
\text { the environment. }\end{array}$ & - 5-10 year plan. & & $\begin{array}{l}\text { - Planning for } \\
\text { eternal use of the } \\
\text { land. }\end{array}$ \\
\hline \multirow[t]{2}{*}{ Passion } & $\begin{array}{l}\text { 1. Love of the } \\
\text { Job }\end{array}$ & & $\begin{array}{l}\text { - Sacrifices many } \\
\text { other aspects of } \\
\text { life to farm. }\end{array}$ & $\begin{array}{l}\text { - Built farm from } \\
\text { almost nothing to } \\
\text { a very big firm. } \\
\text { - Employees are } \\
\text { passionate. }\end{array}$ & $\begin{array}{l}\text { - Farming is a life } \\
\text { goal, not just a } \\
\text { business goal. }\end{array}$ & $\begin{array}{l}\text { - Farming is the core } \\
\text { of the life } \\
\text { experience. }\end{array}$ & $\begin{array}{l}\text { - Farming is a value } \\
\text { and a vision of } \\
\text { what human life } \\
\text { means. }\end{array}$ \\
\hline & 2. Practicality & $\begin{array}{l}\text { - Almost went broke } \\
\text { due to } \\
\text { untrustworthy } \\
\text { buyers. }\end{array}$ & $\begin{array}{l}\text { - Knows farm must } \\
\text { make a profit to } \\
\text { keep going. }\end{array}$ & $\begin{array}{l}\text { - Invests heavily to } \\
\text { grow the business. }\end{array}$ & $\begin{array}{l}\text { - But makes sure } \\
\text { the costs do not } \\
\text { drive the farm } \\
\text { under. }\end{array}$ & & $\begin{array}{l}\text { - The farm has to } \\
\text { perform. }\end{array}$ \\
\hline
\end{tabular}

